\title{
Andrzej Wójtowicz
}

Uniwersytet Kardynała Stefana Wyszyńskiego w Warszawie

ORCID: 0000-0002-0000-1113

DOI: https://doi.org/10.21697/ucs.2020.26.1.03

\section{PRZYCZYNEK DO IDEOGRAFII POJĘCIA CAŁOŚCI SPOŁECZNEJ}

\author{
A contribution to an ideography of the notion of social entity
}

\begin{abstract}
Streszczenie
Idea całości pojawia się w każdym rodzaju i gatunku myśli społecznej. Jej pojęcia ustanawiają myślenie społeczne i myśl społeczną pierwej, zanim doczeka się ona jakiejś teorii siebie samej. Gdy się jej dorobi, zasady sprecyzowane w procedurach metodologicznego i teoretycznego holizmu mają ugruntowanie w intuicjach i pojęciach ogólnych, jeśli tylko dają się one wysłowić w językach naturalnych. Pojęcia całości społecznej fundowały podstawy socjologii i pytania o ontologię rzeczywistości, którą opisują. W szczególności miały one i nadal mają udział w kształtowaniu dyskursu teoretycznego nauk społecznych. Od początku ich samowiedzy teoretycznej, od czasu dyskusji z przełomu XIX i XX wieku o statusie naukowym socjologii, uzasadnienie wiedzy socjologicznej domagało się przygotowania filozoficznego, odpowiedzi na pytanie, czym jest jej przedmiot jako struktura ontologiczna. Artykuł przedstawia te odpowiedzi w wybranych konfiguracjach dyskursu o narodzie na przełomie XIX i XX wieku w Polsce.
\end{abstract}

Słowa kluczowe: nowoczesność, całość społeczna, naród, byt i bycie społeczne

\begin{abstract}
The idea of wholeness appears in every kind and genre of social thought. Its concepts establish social thinking and social thought before it would have some theory of itself. When it is achieved, the principles specified in the procedures of methodological and theoretical holism are grounded in intuitions and general concepts, as long as they can be expressed in natural languages. The concepts of social totality created the foundations of sociology and questions about the ontology of the reality they describe. In particular, they have had and still are involved in shaping the theoretical discourse of social science. From the beginning of their theoretical self-knowledge, from the time of the discussion on the scientific status of sociology at the turn of the 20th century, the justification of sociological knowledge demanded philosophical preparation, an answer to the question of what its subject is as an ontological structure. The article presents these answers in selected configurations of the discourse about the nation at the turn of the nineteenth and twentieth centuries in Poland
\end{abstract}

Keywords: modernity, social entity, nation, social wholeness, being and social being

\section{Postawienie problemu}

Idea całości pojawia się w każdym rodzaju i gatunku myśli społecznej. Jej pojęcia ustanawiają myślenie społeczne i myśl społeczną pierwej, zanim doczeka się ona jakiejś teorii siebie samej. Gdy się jej dorobi, zasady sprecyzowane w procedurach metodologicznego i teoretycznego holizmu mają ugruntowanie w intuicjach i pojęciach ogólnych, jeśli tylko dają się one wysłowić w językach naturalnych. W mitach założycielskich kultury greckiej, kiedy chaos wyłaniał z siebie poszczególne byty, ich określenia wskazywały na jakąś 
gatunkową i rodzajową całość, której były częścią. Idea całości pierwotnie należy do myślenia rodzajami i gatunkami. Per genus proximum et differentia specificam, przez rodzaj najbliższy i różnicę gatunkową dany byt określa swoją istotę albo jest przez nie określony. Arystoteles uczyni z idei całości naukę, w każdym razie jej początki w myśleniu filozoficznym. Systematyka bytów żywych Arystotelesa umożliwiła elementarne klasyfikacje i kategoryzacje. Teofrast, uczeń Arystotelesa i Platona, zastosuje ją do świata roślin. Potem ideą całości gospodarować będą badania systemów. Całość jako system w naukach przyrodniczych inspirująco wyprzedzi nauki społeczne.

Być to należeć do jakiejś całości. Odkrywanie przynależności czegoś do całości gatunkowej jest pierwszym zadaniem wiedzy rozumnej. Coś, czemu nie daje się przypisać przynależności całościującej, wypada z bycia bytu. Bycie bytu jest urzeczywistnianiem logiki całości. Bycie jest logiczne, o ile byt jest częścią całości. Ta pewność na długie lata wyznaczy solidność perspektywy heglowskiej, aż się ostatecznie załamie pod wpływem pozytywizmu. Jej przedłużania w marksizmie rozmaitych generacji i filozofiach krytycznych odmawiają sobie prawa do pewności pierwotnej, że pojęcie całości charakteryzuje byty realne społecznie bez konieczności uwzględniania ich autokorekt w ruchu rozmaitych emancypacji, wolności stanowienia. Byt absolutny jest wyjątkiem. Nie ma całości, do której należy. Nie ma momentu emancypacji, choć ma moment absolutnej wolności. Sam jest dla siebie całością.

Tak możliwa jest ontologia, nauka o byciu bytu. Platon miał w tej sprawie pogląd odmienny: „Być to partycypować w idei bytu. Czy nie powiemy o każdym człowieku, że stanowi on jako taki jedną i odrębną całość" - pyta Platon (Platon 1960: 38). W rozwinięciu Plotyna jedna i odrębna całość człowieka jest nią w relacjach z Absolutem i światami natury. Adam Krokiewicz, tłumacz Plotyńskich Ennead, tłumaczy rzecz następująco: „Arystoteles wy równywał duszę z ciałem, tworzył z nich całość, zacierał, ile możność, ich wzajemne różnice. Plotyn idzie nie za Arystotelesem, lecz za Platonem i uwydatnia niewspółmierność pomiędzy duszą i ciałem, która sprawia, że dusza w połączeniu z ciałem przestaje być jedną duszą i dzieli się niejako na

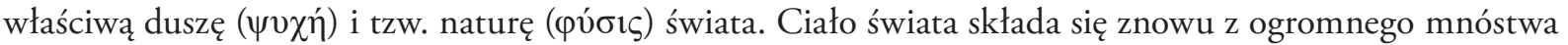
ciał poszczególnych. Nie przenikają się one wzajemnie na podobieństwo części „umysłu”, lecz są odrębne, oporne i zawsze mniejsze od wspólnej całości. Wspólna całość, czyli ciało świata, ma charakter ustrojowego zespołu, podobnie jak złożone z wielu różnych członków ciało jednego człowieka, jak jedno miasto lub państwo, jak jedna armia w marszu lub grupa choreutów w tańcu. W zespołowym charakterze »ciała« tudzież w podziale niecielesnej "duszy« widnieje znamienna dla świata zmysłów "przewaga wielości nad jednością. Z drugiej strony trzeba pamiętać, że i tutaj także zwycięża i panuje ostatecznie jedność»" (Plotyn 1959: LI).

Wielość i jedność to kategorie ontyczne. W odniesieniu do zbioru ludzi na tym samym terytorium, wspólnego pochodzenia i wspólnoty praw stosuje się tedy platońskie ujęcie ontyczne całości politycznej o strukturze polis (Platon 1960: 144). Polis to jest całość superstrukturalna, to znaczy ukonstytuowana prawem boskim i ludzkim, o ile ich przestrzega. Polis, jeśli jest zbiorowością wspólnoty ethosu, prawa i cnót w hierarchicznym ich uporządkowaniu - od najwyższej, czyli rozumu, do niższych, w tym sprawności zachowywania ładu zbiorowego, gwarantuje sobie i swym obywatelom wszelakie pomyślności. Rzeczpospolita platońska jest całością superstrukturalną.

Od Poppera wiadomo, że rządzi ona doświadczeniem i ideami totalitaryzmu (Popper 1993). Od Hannah Arendt wiadomo zaś, że ruch totalitarny ma społecznie wyraźne kontury historyczne i konfiguracje kulturowe (Arendt 1983). Z procedur psychoanalitycznych Ericha Fromma i studiów Theodora Adorno wiadomo, że związki superstrukturalnych całości społecznych w granicach historycznych relacji chrześcijaństwa i struktury społecznej w Europie od ery konstantyńskiej nieustanie produkowały rozmaitość tendencji, postaw i zachowań totalitarnych (Fromm 1997; Adorno 1994).

Jak całości społeczne, pomyślane i odkrywane w środkowej nowoczesności, tzn. od połowy XIX wieku w myśli społecznej i teorii socjologicznej, stają się ich teorematami głównymi? Do jakich konsekwencji praktycznych prowadzą? Interioryzacja idei całości społecznej i jej następstwa w odpowiedziach na pytanie o procesy jej tożsamości ustanawiały pierwsze problemy socjologii. Całość i tożsamość społeczna wymieniają się warunkami możliwości swych poznawczych i praktycznych realizacji. Co jednak, gdy całościujące myślenie spostrzega zjawiska niepodpadające pod logikę całości? 
Idea całości zakłada arystotelesowską zasadę wyłączonego środka. To, co się z nią nie zgadza, musi się pojawić w polu jakiejś sprzeczności. „Sprzeczność jest tym, co nietożsame w aspekcie tożsamości” (Adorno 1986: 10). To ustalenie Adorna prowadzi do gruntownego przekształcenia przedmiotu w naukach społecznych. Jest nim to także i przede wszystkim, co swe istnienie zawdzięcza ruchom emancypacyjnym z przymusu tożsamości z jakąś dominującą formą całości społecznych. Prawomocność bycia bytu nietożsamego z całością jest momentem wolności. Pojawia się pytanie, jak zachowują się całości społeczne skategoryzowane myślą społeczną, na jakie własne cechy wskazują, gdy przychodzi im konfrontować się ze sobą w ruchu rywalizacji o priorytet czynnika konstytuującego ład zbiorowy i rozwojowy. Czym jest całość społeczna narodu, klasy, państwa, czym każda inna całość: kultura, prawo, serie pojęć całości społecznych, miasto, wieś, warstwy i środowiska w konkrecie ich historycznych struktur, czym religia, nauka, cywilizacja, gdy każde z nich żąda dla siebie pozycji uprzywilejowanej w hierarchizacji praw istnienia i utwierdza, uzasadnia wybór priorytetu znaczenia i poznania? Czy dochodzi do głosu, jak w postmodernizmie, równouprawnienie rozmaitych całości pod warunkiem, iż wyzbyły się one pojęcia i poczucia hegemonii, absolutu? Słowem, czy ich alternatywa, ruch relatywizacji wszystkiego, co społeczne, jest procesem racjonalnie do opanowania, uprawomocnienia? Czy znosząc podstawy idei i doświadczenia całości społecznych, myślenia holistycznego, nie znosi się gruntownie możliwości jakiegokolwiek przedmiotu w naukach społecznych, a ich roszczenia nie redukuje do metody niekończącej się nigdy narratywistyki? Jakie warunki musi spełnić socjologiczne poznanie, by jeszcze zostało na terenie nauki swego gatunku i pochodzenia, to znaczy nauki społecznej? Pytania idą dalej w stronę rozważań fundamentalnych, etycznych, teologicznych, jak w myśli katolickiej, która głosi, że „część istnieje dla całości, a więc dobro części jest podporządkowane dobru całości; że całość jest dla części czymś określającym i że nie można nią rozporządzać na swoja korzyść” (Hamelin 1966/7: 203).

Wysoka modernizacja, czyli ostatnia dekada XIX wieku, godziła historyczne narracje z rygorem postępowania naukowego. Uznawano dość pobieżnie i powszechnie, jak się okaże, także pochopnie, że same narracje historyczne, etnograficzne, etnologiczne czy socjologiczne zależą do systematycznej, bezstronnej, uważnej i rygorystycznej kolekcji, odsianych z rozmaitych zanieczyszczeń faktów społecznych. Konsekwencja indukcyjna miała ową kolekcję zabezpieczyć przed urojeniami nadmiernego uogólniania, a tam, gdzie zeń korzystała, miała gwarantować poprawność i dobrze uzasadnione konkluzje. Ostatecznie nie obroniła się jednak przed zarzutem historycyzmu. Jakie to miało skutki dla burzliwie rozwijającej się socjologii, łatwo zauważyć. Sukcesywny historycyzm, przynajmniej wedle Nędzy historycyzmu Poppera, gładko powiązał ogólne idee ewolucjonizmu, naturalizmu, organicyzmu i romantycznego światopoglądu, wedle którego ludzie są w permanencji zdolni do kształtowania całości społecznych według własnych celów, zamiarów, wyobraźni. W ten sposób udało mu się znaleźć ewolucyjne i naturalistyczne tropy zasady narodowości, emancypacji i wolności dla ruchów społecznych drugiej połowy XIX stulecia.

Ewolucyjny pozytywizm, następstwo pozytywizmu Auguste’a Comte’a i badań Johna Stuarta Milla, w dziedzinie zaś historycznej pozytywizm Leopolda von Ranke chlubiły się promocją metody naukowej, w granicach której poszczególne dane empiryczne zawsze znajdowały miejsce w jakiejś całości. Onże sam kierunek nadziei motywował Beatrice i Sydneya Webbów, gdy zakładali w 1895 roku London School of Economics. Sojusz liryki idealizmu historycystycznego i pragmatyki empiryzmu brytyjskiego miał uzasadnić wiarę w ciągłe doskonalenie ludzi i instytucji, jeśli tylko obie strony procesów kształtowania wzajemnych relacji zachowują się rozumnie. Więź heglizmu ze społecznym organicyzmem, przynajmniej na terenie dziedzictwa socjologii Spencera, pozwalała głosić prawa realizującego się tam ducha dziejów. Szło tylko w szczegółach o odpowiedź na pytanie, jak realizowany jest ład całości uwzględniający rygory całości zinstytucjonalizowanej na współmiernie sobie, zróżnicowanym poziomie strukturalnym. Pytanie to miało liczne rozwinięcia teoretyczne w koncepcjach instytucjonalnej dyferencjacji, od klasycznych: Comte’a, Durkheima i Spencera po współczesny nowy instytucjonalizm Waltera W. Powella i Paula J. DiMaggio (Powell, DiMaggio 1991) z teorią instytucjonalnej autonomii, upośredniczony osiągnięciami socjologii Parsonsa, Eisenstadta, Luhmanna, Lenskiego czy Turnera (Abrutyn 2009: 449-465). 


\section{Nowoczesność i idea całości społecznych. Trajektorie polskie}

Schyłek wieku XIX i początek XX zgromadziły wszystkie problemy nowoczesności. Na terytoriach Polski porozbiorowej wypromowały wszakże inne ich konfiguracje niż te, które skupiały uwagę w Europie Zachodniej i za Atlantykiem (Łepkowski 1967). Emancypacja, rozwój, rewolucja przemysłowa, ruchy modernistyczne w nauce, sztuce, religii, nowe formy konfliktu społecznego i ich ideologie zapowiadały nowe debaty i przekształcenia na skalach globalnych. Nowoczesność tego czasu obchodziła się jeszcze z szacunkiem z imperiami, ale nie prolongowała im żywota dłuższego niż jedno pokolenie. Nowoczesność po polsku miała inną twarz twarz konspiracji, twarz maski. W takich formach pytania o konflikt, wojny, sztukę, religię czy naukę skłaniały do odpowiedzi radykalnych, utajonych, aliści w dostępnych środkach wyrazu, które miały każdorazowo pieczątkę Дозволено цензурою - „dozwoleno cenzuroju”, rozmaite imprimatur, nibil obstat. Nie rozwiązywała żadnych problemów, ale warunkowała ich postawienie. Uruchamiała same trudności. W miejscach, gdzie ludzie w niewoli powici marzyli o wolności, elementarny warunek nowoczesności, imperium rosyjskie ustanawiało władze, panowanie we wszystkim, co stanowiło o ładzie zbiorowym i przyszłości. Imperium pruskie, potem, od 1871 cesarskie, wchłaniało Kulturkampfem zakazy tożsamości innej niż germańska. Imperium austro-węgierskie pragmatycznie pozwalało na autonomię poszczególnych instytucji w praktyce józefińskich reguł politycznych. Tylko w jednej dziedzinie, w kulturze, ich możliwości były ograniczone, złudzenia zaś większe. Zaborczość imperium rosyjskiego nie nauczyła się strategii Kulturkampfu, stosowała własne, jeszcze bardziej samowolne, ciemiężycielskie, zwłaszcza po powstaniu styczniowym, po likwidacji Królestwa Kongresowego, w owym Priwislinskim kraju, gubernialne praktyki; prusko- cesarska zaś nie poskramiała siły zmyślnej adaptacji do prawa, które już ustanowiła elementarnym zasobem przynależności politycznej; austriacka manewrowała pośród przyznanych namiastek autonomii produkcją intencjonalnie i żywiołowo napięć. Ludzie Kościoła i ludzie sztuki, w szczególności literatury i krytyki kultury, polityki i ekonomii, generacja niepokornych, inteligenci pierwszego pokolenia tej warstwy co dopiero zdobywali się na samodzielność ideową (Cywiński 2010), kulturową i ekonomiczną. Poszukując szczelin wolności w kulturze chronili ciągłość tożsamości społecznych narodu, który w horyzoncie swych możliwości nigdy nie utracił wolnościowych podstaw istnienia, choć tracił inne. Prawomocność zróżnicowania w kulturze i autonomii jej odmian w nauce, moralności, religii, obyczaju, sztuce, w literaturze, w myśleniu odziedziczyła romantyczne misje, jak podołać wymaganiom wolności, gdy jej oprawcy sprawują władzę. Bunt, rewolucja, kontestacja, powstanie, irredenta czy pola koncesjonowanej samodzielności, pozytywistyczne praca od podstaw, dostosowywanie się do warunków państwa, w którym przywilejem jest służba za ceną zdrady, co najmniej za cenę podwójności lojalności względem woli imperium i woli, może obowiązku czujnego wypatrywania szans wolności, haraczem politycznym opłacana własność majątkowa i spryt inteligencji liczący się z ofiarą w służbie nowoczesnego narodu. Jak uzasadnić ową nowoczesność, gdy jej podmiot, naród, jedyna całość dostępna wolności myśli, nie odnalazł jeszcze swych społecznych podstaw, a do określenia swej tożsamości, idei scalających musiał użyć narzędzi sprzed swego nowoczesnego arche: kultury, literatury, pamięci, tradycji, legendy, baśni (Cywiński 2016), więzi społecznej, instytucji ciągłości społecznej, przewagi integracji nad dyssypacją, form wyobraźni zbiorowej, instrumentów odkrywania siebie, a przede wszystkim państwa. Trzeba było ruchu umysłowego, który odzyska ich znaczenie wśród nowej konfiguracji problematyki autonomii i wolności, połowiczności ustawicznej i podmiotowości zupełnej. Ex litteris libertas (Cywiński 2010) toczy się na ziemiach polskich nieustannie, bo omnes autem homines natura libertis studio incendi et condicionem servitutis odisse (badanie natury wyzwoleńców ludzkich ma nienawidzić stanu niewolnictwa, jednak podpalić wszystkich), co powtarzano w edukacji klasycznej, wtedy jakże licznej, za Cyceronem. Odmiany jej form, miejsc, postaci, osób i instytucji gotowały się na konfrontację wśród - jak zwykle nośnych - idei rewolucji i niepodległości po stronie podmiotowości zupełnej i koncepcji autonomii po stronie połowiczności ustawicznej. Trzecie drogi interesowały oportunistów, tych zawsze najwięcej. Wśród tych dróg konserwatyzm stawiał najważniejsze pytania o warunki możliwości wolności, cnoty obywatelskiej, o interes zbiorowy, o praktykę polityczną zgodną z rozumem. Konserwatyzm zawierza się racjonalizmowi po upadku warunków jego realizacji, udziela mitologicznych odpowiedzi. Były odpowiednie, by uszanować przeszłość romantycznego, irredentystycznego zapału i nieobecnego już klasycznego ładu, i kpił z nich niemiłosiernie, widząc w nich wady narodu, który nie dostrzegał swych partykularnych interesów jako jedynych możliwie realistycznych. 
Partykularność interesów to siła konserwatyzmu zadowolonego - jak mawiał Dmowski - partyjnie, odnosząc się do krakowskich Stańczyków i ich naśladowczych wyznawców w Królestwie Polskim, czyli pod zaborem rosyjskim. Samoświadomy konserwatyzm polski od początku swych teoretycznych formuł, to jest od upadku pastwa w 1795 roku i później, zwłaszcza po upadku powstania listopadowego, jest wiarą w źródła mocy nieużytecznych historycznie, dostępnych wszakże myśleniu o ideałach i powinnościach jako tako zdatnych w służbie zachowania pozycji społecznych możnowładztwa. Nie traci ożywiających motywacji solidnej pracy, twórczości, konkurencji. Krzepi solidnością wykształconych i niepokornych jednocześnie. Rozgrywa dramat wolności na gruzach romantycznej nadziei na jego zakończenie w doktrynie ugody i rezygnacji z celów suwerenności państwowej opłaconej zyskiem na przywilejach użytych w służbie władzy zaborczej. Jego przeciwne obozy po stronie irredenty narodowej bądź ruchów demokratycznych, później lewicowych także dysponowały heterogenicznymi rozwiązaniami od skrajnych pomysłów rewolucji społecznych w łączności $\mathrm{z}$ bratnimi w ucisku klasami w łonie państw zaborczych po rewolucje niepodległościowe.

\section{Całość. Hipostazy i aporie}

Dylematy biegunowe, narodowe/rewolucyjne, powszechne/lokalne, podmiotowość zupełna / autonomia, naród/klasa, wolność/interes, legalizm z przymusu albo z wyboru ugody / konspiracja to nic nowego w strukturze rozwoju samowiedzy społecznej poszczególnych środowisk i ugrupowań, ale to nowość historycznie obligująca do przezwyciężenia. Bezkompromisowość, której zawsze blisko do radykalizacji i niezdolności praktycznej swej realizacji, łączy gotowość do ofiary z odległą perspektywą zwycięstwa zza grobu. Finistyczny sukces radykalizmu dzieje się w głowach wydziedziczonych ze wszystkiego, więc ich starania o podtrzymanie walki o wszystko mnożą ofiary złożone w walce o fantomy. Ocalenie ludzkości przez złożenie jej kompletne do grobu nie jest całkiem samosprzecznym programem, ale w radykalizmie zanadto eschatologicznym i cokolwiek stronniczym. Rewolucje krwawe, oprócz amerykańskiej, nigdzie nie rozwiązują problemów, które je do głosu dopuściły, owszem, prowadzą do ich ludobójczych rozmiarów. Terror jest ulubieńcem fanatyzmu, obrońców równości i wolności bez granic dla siebie, nie dla jej wrogów. Ten wzór saint-justowski selekcji użytkowników wolności ustanawia kryteria doboru jego beneficiencji. Gdy różnice i hierarchie są wrogami, życie człowieka nie jest wartością, jeśli on sam nie dekretuje jego użytku. Życie jako wartość pojawia się w użytku jego wymienności na wolność bezgraniczną, dyktaturę samożycia wolności, nie zaś odwrotnie wolności dla życia. Nihilizm nietzscheański przegrywa z wolą mocy wolności, która ustanawia prawa życia i prawa do życia. Genocyd ufundowany pragnieniem wolności i praw człowieka jest historycznym zdarzeniem, recydywą, nie fuszerką czy błędem kultury. Już wtedy prowokacje z pokusy nihilistycznej Sergiusza Nieczajewa dają powód badań nienawiści i rozpaczy w Biesach Dostojewskiego, a w Ptomieniach Stanisława Brzozowskiego, powieści z 1907-1908 roku, inspirują Michała Kaniowskiego, bohatera rozprawy ze wszystkim, co konserwatywne, ugruntowane w tradycji, gdzie „Kościoły tam i księża - panowie i księża. Nic. Siedli chłopu na szyję i krzyczą: ojczyzna” (Brzozowski 1997: 184). A kiedy się nienawiść i rozpacz w szalony, choćby i samotny czyn przemieni, to co wtedy? „Ktoś ty jest, tragiczna siło. Co dajesz moc wytrwania bez świadków? Ktoś ty jest, która żyjesz w bohaterstwie, mężnym czynie, samotnej pracy mędrca? Prawda! Kto daje władzę prawdzie, gdzie jej siła jest? Potężne czucie, że człowiek zwalczy przeznaczenie" (Brzozowski 1997: 158). Michał Kaniowski odwraca romantyczny mit Fausta. Już nie odkrycie przeznaczenia, lecz jego zniesienie w rewolucyjnej praktyce nihilizmu. Fantomizacja antyfaustyczna jest regularnym procesem umysłu w kodach albo, albo. Domaga się realizacji mitycznej w hipostazach całości społecznych klasy, narodu, państwa, w symbolizacjach odwrotu od jakiejkolwiek tradycji, obciążenia sumieniem. „Myśleć o swoich grzechach mogą tylko próżniacy. Człowiek powinien iść w przyszłość" (Brzozowski 1997: 31) - deklamuje Adaś Bielecki, jeden z tych w Ptomieniach, co bezmyślnością rażą nawet Kaniowskiego. Dylematy biegunowe są więc teoretycznie u siebie, w niewyczerpywalnej potrzebie mitu. Nierozwiązane praktycznie, bo brak wstępnego warunku wolności, należą do przyszłości nieznośnej inercją biegunowego napięcia. Gdy historycznie należą do przeszłości, operują innymi kategoriami przeciwieństw: wolny szlachecki naród - republikańska inicjatywa reformy, jak w próbach reformy stanisławowskiej i Konstytucji 3 maja z 1791 roku, albo unowocześnionymi już o programy wyzwolenia społecznego włościan inicjatywami Towarzystwa Demokratycznego Polskiego 
z lat 1840-1847. Kelles-Krauz nazywał je ideałami retrospektywnymi odpowiedzialnymi za świadomość narodową nowoczesnego typu (Snyder 2010: 222). Jedynie w całości doświadczenia i idei narodu miały one pola historycznych szans, stawiając jednak warunki uchylenia dualistycznych rozwiązań i napięć. Poszukiwały tedy modelu rozumności strategii najpierw w poszerzaniu swej społecznej bazy (Dmowski 2013: 107), potem we współpracy z chrześcijaństwem i kościołem łacińskim, ruchami ludowymi albo ruchami socjalistycznymi (Dmowski 2014: 755-782). W Galicji było to zrobić łatwiej niż gdzie indziej, bo po powstaniu listopadowym zyskiwała na uciekinierach z Kongresówki i na rozbudzonych nastrojach i poczuciach narodowości w całym cesarstwie austriackim. „Poczucie narodowe w samym społeczeństwie polskim musiało niejako schodzić w dół. Od szlachty posiadającej do szlachty zdeklasowanej i tych wszystkich grup społecznych, które znalazły się w tym samym społecznym położeniu co najbiedniejsza szlachta... Polskość dla tych ludzi jawiła się otoczona legendą walki o wolność, była równoznaczna z przynależnością do stanu uprzywilejowanego, do szlachty. Ta siła, z jaką polskość nie posiadająca własnej państwowości asymilowała wówczas właśnie w Galicji żywioły etnicznie niepolskie, jest zjawiskiem bardzo skomplikowanym i ogromnie interesującym ze stanowiska historycznego" (Wereszycki 1975: 59).

Model strategii poszerzenia społecznej bazy narodu miał się tedy zalegalizować mentalnie i praktycznie, kulturowo i ekonomicznie w pozyskiwaniu sojusznika w chronicznych wieloznacznościach jego położenia społecznego. Zróżnicowania etniczne są okolicznością narodowotwórczą, gdy ruchy emancypacyjne warstw i poszczególnych osób znajdują się w fazie określania swej tożsamości, jak Piotr Rozłucki z Urody życia Stefana Żeromskiego, ów polski Ulisses odkrywający siebie w polskości swego losu i przeznaczenia (Żeromski 1957). Urodą historii zwie ten proces Bohdan Cywiński (bdw.: 13), co jest - rzecz prosta - skrótem estetycznym krętych dróg stawania się narodów i kultur. Piotr Rozłucki, Michał Kaniowski - dwa modele przemiany faustycznego bohatera. Pierwszy - by odkryć siebie w tożsamości swego pochodzenia i przeznaczenia; drugi by znieść wszystko, co tożsamość z historii bierze. Który mógł uchodzić za podstawę sojusznika w ideokracji narodowej? Pierwszy. Pojawi się jednak model trzeci. Wykształcony przez ludzi Kościoła. Brzozowski doświadczy tego na sobie. Jego konwersja na katolickie chrześcijaństwo kościelne musi się dokonać w centrum kultury i do niego prowadzić. A więc konwersja, przemiana całkowita. Żadnych epizodów, detali obciążających i wspomagających sceptycyzm. Pewność wiary. Iluminacja z lektur newmanowskich, których jest tłumaczem (Newman 1915). Wyjątkowość Brzozowskiego nie znosi żadnej pospolitości, również wśród jego krytyków. Jakoż nie ominęła go, i to w dużych porcjach. Bywało, doczekał się jedynie jej form dominujących, jarmarcznych w przeciąganiu, kim bardziej był i kiedy. Marksista, ale antynaturalistyczny, stronnik myśli socjalistycznej, ale jej zajadły krytyk, filozof, ale bardziej wizjoner, rekonstruktor tradycji narodowej, ale wróg endecji, modernista katolicki, ale w końcu człowiek Kościoła, formy tak bardzo ludzkiej, że już nie potrzebuje nadprzyrodzonych racjonalizacji. Poeta i filozof, jak głosi napis na grobie Brzozowskiego na cmentarzu Trespiano we Florencji, przekraczał przyzwyczajenia, nałogi i habitusy (Miłosz 2000: 11), bo był zawsze na poziomie geniusza kultury, którą nieustannie zapytywał po kantowsku, jak jest możliwa wśród ludzi, gdzie on jest sam jeden (Brzozowski 1979). Krytyk kultury poniżej jej poziomu jest co najwyżej komentatorem. Musi się wygadać, i to mu na ogół wystarcza. W epokach logorei, manii prześladowczej przymusu wypowiedzi, ustanawia styl korekty felietonowej kultury, niekończącej się igraszki w stylu Gry szklanych paciorków (Hesse 1999), gdy znaleźć w nich coś z chętki nienasyconej nigdy potrzeby kombinacji i przetwarzania rzeczy obrzydliwie banalnych. Brzozowskiego zajmowała całość, kultura jako idea całości, to znaczy scalające się idee niezbędne, by żyć autentycznie, odpowiedzialnie za życie bez wyjątku. Praktyka kultury jest obroną życia.

\section{Kościół. Kultura i urząd}

Kościół jako sojusznik w nowoczesnej konfiguracji narodu był do tego przygotowany praktycznie konfrontacją z zaborczą polityką jego ograniczania. Przystosowanie i opór (Jabłońska-Deptuła 1983) uwyraźnione kontekstualnie położeniem w zmiennych zamordystycznie praktykach władz zaborczych uzbrajało determinację przetrwania, choćby w utajonych formach, ale nie gwarantowało sukcesu teoretycznego. Wiedza o wolności w Kościele nie musiała czekać na podjęcie w przełomie modernistycznym na granicach stuleci, XIX i XX. 
Kościół znał jąw rozmaitych gatunkach, praktycznych i teoretycznych, umiał ją przechowywać i przekazywać, również wtedy, gdy jej zakazywał regularnie przez stulecia swego historycznego istnienia. Jej doświadczenie było - rzecz prosta wcześniejsze - względem jej formuł podstawowych. Jej prefiguracja w Kościele pierwszych czterech stuleci chrześcijaństwa ustanawiała indeks pojęć i sytuacji teologicznie i filozoficznie elementarnych. Era konstantyńska i potem uniwersum Zachodu jako kultury była jej argumentacją główną od przełomu karolińskiego w VIII wieku, a jej wcześni autorzy, od św. Augustyna począwszy, zmagali się z wyznaczeniem jej gwarancji niezbywalnych w dowolnych formułach ortodoksji i ortopraksji. Ich przeciwieństwa, herezje, dotkliwie uczą wolności praktycznie, a ich największe demonstracje, jak w przypadku reformy luterańskiej, zdefiniowały procesy historyczne i wyznaczyły im progi ciągłości i zerwania. Konstantynizm w Kościele i konstantynizm Kościoła jest strukturą historyczną, z wnętrza której pochodzą zmienne problematyzacje wolności. Poszczególne wszakże doktrynalne składniki ortodoksji i ortopraksji w Kościele niełatwo dawały się uzgadniać z ideą narodu, jeżeli tej prawomocność zakładała bezwzględny horyzont wolności. Ktoś, kto należał do wyznawców obu idei naraz u schyłku wieku XIX i początku wieku XX na ziemiach polskich, albo raził wybitnością wymagań niedostępnych pospolicie, albo musiał je kontaminować taktykami jakiegoś kompromisu i mało chwalebną oczywistością niemożliwości uzgodnień kompletnych. Zapożyczenia romantyczne z mesjańskiego arsenału narodowego posłannictwa Polski jako Chrystusa Narodów straciły po klęskach powstańczych motywacyjną siłę. Zapożyczenia z idei narodu wybranego nie nadawały się do użycia, bo zastępstwo w tej roli dobre było jedynie w utarczkach parafialnych. Konkurencja z oryginałem raziła megalomańską fuszerką. Nadawała się do inscenizacji imitacyjnych i polemik o prawo do autentycznej reprezentacji cierpiętniczego losu wygnańca z wolności. Do publicznych debat się nie nadawało. Nie dlatego zresztą, że jej własność ekskluzywistyczna, wyjątkowa, pozbawiała możliwości użycia jej przez innych. Dlatego, że jej treść i norma pochodziła z nadania, daru i wyboru boskiego, do którego nikt poza wybraniem nie miał dostępu, jeśli chciał ugruntować swe racje, cele, wartości w polu racjonalności, na terytoriach niezależności sądu od autorytetu pozahistorycznego. Naród jest profanum historycznym i strukturalnym. Gdy poczyna spoufalać się z sacrum, dzieli jego chroniczną ambiwalencję, strukturę i antystrukturę. Klęska uzurpacji nie usprawiedliwia się jej próbą, ale niedorzecznością założeń, których jest wynikiem. Podobnie romantyczny spór z Bogiem o przywództwo w narodzie wynagradza tylko tych, co się nie mają za boskiego konkurenta, lecz sługę w służbie uzurpatorskiej ironii. Megalomania nie jest do pogardzenia, jeśli stać ją na rzetelne rachunki szans. W innych przypadkach jest kostiumem zużytym w zawsze przegranych, kabotyńskich bojach o wygląd. Utajniony w niej narcyzm gorzko przemawia zapowiedzią niepowodzenia. Zresztą kandydatów w rywalizacji megalomanii narodowej było zbyt dużo, by podjąć jej szranki, choć wielu na ziemiach polskich było z tym do twarzy (Bystroń 1924). Zostaje idea niepodległości wskazująca na łączność motywu wolności ludzi i narodów.

Byli więc Polacy narodem, bo chcieli nim być, bo się w nim odnalé́li w byciu społecznym wolności. Interesy można robić z kimkolwiek i takich jest gromadka nielicha. Wolność wymaga osoby we wspólnocie. W zniewolonej wspólnocie nie ma wolnej osoby ludzkiej, choćby nią była w swych definicjach. Nie idzie o status wolnej woli w osobie - to problem filozofii od starożytności (Berlin 1994) nieobojętny, rzecz prosta, w rozważaniach socjologicznych - ale o status wolności w relacjach społecznych. Idzie o pytanie, jak wolność jako wartość i warunek konstrukcji całości społecznej narodu urzeczywistnia ją jako inną wartość główną. Hasło „Za waszą i naszą wolność” ma głęboki sens antropologiczny i oczywistość socjologiczną. Historycznie należy do imperatywów nowoczesności. Podzielają je stronnicy narodowej demokracji, socjaliści, rzecznicy reformatorskich ruchów ludowych, radykałowie rewolucyjni. Konserwatyzm trzyma się odeń z daleka. Kościół katolicki nie zna jeszcze tego języka. Będzie go testował, najpierw w próbach katolickiej nauki społecznej, potem w jej wykładni pontyfikalnej w Rerum novarum Leona XIII. Otworzy się nań po 1871 roku, po Soborze Watykańskim I, by skonfrontować jego ryzyka w ruchach modernistycznych. Wolność, jako kategoria osobowej egzystencji, dar w interpretacjach teologicznych, wartość w relacjach społecznych, cel w staraniach politycznych, jako wezwanie w interpretacjach etycznych, obowiązek w interpretacjach ideologicznych, dobro w interpretacjach moralnych i warunek samowiedzy narodowej w interpretacjach historycznych, gwarantowała samodzielność danej całości społecznej i jej prawomocność. Pojęcie wolności ustanawiało w kulminacjach procesów nowoczesności wszystkie kategorie myśli odpowiedzialnej za położenie 
całości społecznych: narodu, klasy, państwa. Ideę tę wysłowił i wysławiał najpełniej Roman Dmowski. We wstępie do Myśli nowoczesnego Polaka z 1902 roku pisał: „Myślami swymi chcę się dzielić nie z tymi, dla których naród jest martwa cyfrą, zbiorowiskiem jednostek, mówiących pewnym językiem i zamieszkujących pewien obszar: zrozumieją mnie tylko ci, co widzą w nim nierozdzielną całość społeczną, organicznie spójną łączącą jednostkę ludzką niezliczonymi węzłami, z których jedne mają swój początek w zamierzchłej przeszłości - twórczyni rasy (identycznej synonimicznie z narodem - przyp. oryg.), inne w znanej nam historii - twórczyni tradycji, inne wreszcie, mające wzbogacić treść tej rasy, tradycji, charakteru narodowego, tworzą się dziś, by w przyszłości dopiero silniej się zacieśnić" (Dmowski 1980: 74). W pojęciu narodu w warunkach niewoli jest wszystko, co wskazuje na przeciwieństwo pojęcia klasy, kultury lub państwa jako innych, konkurencyjnych całości społecznych. W doktrynach, w których dochodziło do hierarchizowania ich znaczeń, absolutyzacja poszczególnych całości, odpowiednio, narodu, kultury, klasy i państwa, wyznaczała miejsca podporządkowane swym odniesieniom, narodu - klasie społecznej, narodu - kulturze, państwu klasie czy klasie w dowolnych wariantach państwu, kulturze i narodowi. Pisał Roman Dmowski w broszurze Nasz patriotyzm (1883): „Nie powinniśmy się (...) dziwić, że nasi przedstawiciele wielkiego kapitału wolą się udawać pod skrzydła opiekuńczego rządu, dążącego do zagłady naszego narodu, aniżeli zgadzać się na wzrost tych sił narodowych, których rozwój jest niepożądany nie tylko dla rządu zaborczego, ale i dla nich samych" (Dmowski 1990: 54). Ów wzrost, którego realistyczne przewidywania R. Dmowskiego zakładały najpierw szeroką, tak jak się da, autonomię, potem samodzielność polityczną w łączności z Rosją, na koniec niepodległość w warunkach starcia mocarstw zaborczych między sobą. Dodatkowo zakładał unarodowienie kogo się dało, więc ludu przede wszystkim, włościan i mieszczan, a po unarodowieniu zdolności produkcji kapitału także klas ekonomicznie wyższych. Myśli tej nie brakowało niczego z realizmu i racjonalności, kompetencji przewidywań. Pozbawiona była jedynie profetyzmu niezbędnego w rywalizacji o umysły i serca. W myśli Kellesa-Krauza, dla której zbieżność historyczna ruchu narodowego i socjalistycznego nie wymuszała rezygnacji z wyzwolenia obu naraz, ustanawiała ona paradygmat urzeczywistniania wolności, wolnej krytyki, wolnej inicjatywy, wolnego społeczeństwa. W istocie tej perspektywy przeciwieństwa znoszą się historycznie, dając każdej z ich stron pozór dominacji w warunkach niepodległego bytu państwowego.

\section{Stanisław Brzozowski. Dziejowość istnienia narodowego}

Myśli tej zabrakło poparcia w miejscach, gdzie je Kelles-Krauz głosił, na forach II Międzynarodówki, jak i żarliwości fanatyka, jak na potomka barona przystało. Była wszak dość silna, by inspirować S. Brzozowskiego, później niepodległościową i przede wszystkim lewicową inteligencję, dla której opuszczenie ojczyzny nigdy nie było opuszczeniem narodu, co w części wyznawały już romantyczne formacje emigracyjne ludzi powstańczej walki, ludzi sztuki, Kościoła czy uniwersytetu. Odkrycia historyczności i uspołecznienia samego zjawiska, owej całości społecznej narodu, kultury, klasy czy państwa w pismach Dmowskiego czy w odmiennych perspektywach Kellesa-Krauza (Snyder 2910), Krzywickiego (Kurczewska 1979), Abramowskiego (Szacki 1991), Limanowskiego (Limanowski 1906; 1918; 1911; 1946), Brzozowskiego (Mencwel 1990), jak legionu innych autorów z ostatniej ćwierci XIX wieku i jego końca, czyli - jak powszechnie deklamują historycy - do wybuchu I wojny światowej 28 lipca 1914 roku, odsłoniły mnogie normatywne i aksjologiczne własności, ale także ich dotkliwe nieobecności, brak, jak pisał Stanisław Brzozowski, bezpośredniej poznawczej szczerości idei człowieka, która już nie ma innych warunków urzeczywistnienia jak tylko w horyzoncie swej historyczności. W historyczności idei człowieka, by mogła ona jeszcze raz przemówić ocaleniem jej podmiotu, ocaleniem wartości osobistego życia, trzeba zidentyfikować żywioł i ład, znaczenie i sens. „Nie idzie tu oto, czym jest życie, człowiek, ale o stosunek tego wszystkiego do zagadnienia narodowej niepodległości, istnienia narodowego. Ale naturalnie, że dzieje się to nie w formie świadomego rozkładu planów i stosunków, lecz w drodze bezwiednego, instynktowego podporządkowania wszystkich czynności umysłowych zagadnieniom specjalnym, historycznie określonym” (Brzozowski 2007: 16). Ów moment „narodowego istnienia”, idei równie ogólnej jak idea człowieka, niepodległości, wolności, kultury, reglamentuje historycznie ich realizacje. Potrzebuje tedy zrozumienia aktywnego, pracy zawierzającej sobie samej, pewnej siebie, swego miejsca w procesie współtworzenia całości społecznych, narodu, kraju, kultury, Europy. W Legendzie Mtodej Polski 
S. Brzozowski włącza ją w procesy uhistorycznienia. „Historia wytworzyła nas - marzyć o uniezależnieniu się od historii jest to marzyć o samounicestwieniu, o rozpłynięciu się w eterze feerii i baśnie. Jest naszą istotą to, że jesteśmy Europejczykami, żyjącymi w tym a nie innym miejscu. Nasze ja to nie jest coś stojącego na zewnątrz historii, lecz ona sama; nie ma możliwości wyzwolenia się od niej, gdyż nie ma w nas włókna, które by do niej należało. Gdy więc łudzimy się, że w naszym wnętrzu jesteśmy samotni i niezależni, wyrywamy z właściwego związku to, co tylko w związku tym pojmowano być może. Nasza metafizyka jest zawsze mitologią społeczną, przypisuje bowiem samoistne znaczenie momentom społecznego istnienia” (Brzozowski 1990: 705). Nikt jak Brzozowski nie odkrywa potrzeby idei całości w kulturze, która tłumaczyć może kształtowanie się dominującego historycznie typu społecznego istnienia ludzi i narodów. „Należeć do trwałego świata, stanowić jego moment organiczny - takim było zawsze określenie kultury. Odpowiedzialność wobec historii - oto jest rys zasadniczy każdej mającej doniosłość kulturalną działalność. Wrogiem najgroźniejszym jest dziś życie bez historycznego planu, miękki i bezkostny subiektywizm” (Brzozowski 1990: 717). W kulturze europejskiej tamtego czasu Brzozowski nie był sam, choć granicznie samotny w kulturze polskiej. Czyż Marsz Radetzky'ego Josepha Rotha, trzydzieści lat później, nie odkrywa tego samego w rozpadającej się kulturze cesarstwa Austro-Węgier co Brzozowski w kulturze polskiej? A badanie możliwości Cztowieka bez wtaściwości Roberta Musila, czterotomowej powieści pisanej latami do końca życia (1930-1943), czy nie gromadzi efektów rozpadu całości kultury europejskiej, choć, tak jak Marsz Radetzky’ego, koncentruje spojrzenie na losach Cekanii, owego nostalgicznie tylko zrozumiałego tworu Austro-Węgier, który bardziej niż politycznie, jako imperium, był ideą kultury, owej całości, w której każdy, jak Brzozowski w katolicyzmie, w Kościele i w tradycji przetwarzanej nieustannie w stronę typu dziejowego, mógł rozpoznać siebie. Tym też była nostalgiczna idea Polski dla Polaków każdej emigracji. „Dla całej emigracji Polska przyszła miała być ideą, ideałem swobodnego ludzkiego życia” (Brzozowski 1973: 223).

Ideografia Brzozowskiego to istotnie, jak wszechstronnie, wielokrotnie pisał Andrzej Walicki, „filozofia dojrzałości dziejowej” (Walicki 1990: 5-66). „Tworzyć nową kulturę znaczy to tworzyć nowy typ życia. Narastając, walcząc o swe istnienie, wyłoni on z siebie to, co, gdy będzie dokonane, ukaże się jako systematyczna całość” (Brzozowski 1990: 717). Pojęcie i idea całości, struktura historyczna i społeczna, projekt kultury, forma życia wchłania i nadaje sens subiektywności, poszczególnej osobie i poszczególnej pracy. I ten do niej należy i ją utwierdza, co jest na poziomie jej wymagań, reprezentuje jej idee główne, jej logikę i wartości, co jest - jak sam Brzozowski - jej geniuszem. Bliska tej charakterystyce, jeśli nie identyczna z nią jest troska Roberta Musila. „Miejsce człowieka jest tam, gdzie napotyka najwyższe możliwości i doznaje największego rozwoju swych sił - gdyż tam przyczynia się do najintensywniejszego wzmożenia życia jako całości” - wyznaje Robert Musil glosolalią swojej bohaterki, Deotymy, żony dyrektora Departamentu, niejakiego Tuzziego, w rządzie CK Austrii (Musil 1971: 126). Jeśli Deotyma rozwiązuje swe problemy myślą o idei całości, kto może się jej oprzeć, tym bardziej że to niewiasta wściekle urodziwa, tedy dodaje jej aspekt erotyzmu, który wtedy, już z aktywności Zygmunta Freuda, wiedeńczyka co się zowie, preparował całości kultury jako źródła cierpień. Do Przykuckiego, Kaniowskiego, wypada dodać sekwencję von Trotta z Marsza Radetzky'ego oraz Deotymę, Urlicha i Arnheima, figury Cztowieka bez wtaściwości, wszyscy z rozpadu kultury, z dyssypacji imperiów, z destrukcji idei całości życia. Trzeba tę ideę tedy odnaleźć lub wynaleźć inaczej. Jeśli się nie uda, a tak staje się najczęściej, skutkiem jest niekonsolacyjna tęsknota, nostalgia zgoła neuropatyczna albo bunt, albo rozpacz. Hegel i Marks zrobili swoje, zapowiedzieli ruiny. Doczekali się ich w swych wnukach. Pora na całości innego typu, kultury i narodu. „Polska tradycja dziejowa w tej formie, w jakiej działa u nas na umysły, jest bardzo złym przygotowaniem dziejowo-biologicznym do zwycięskiej walki na dzisiejszym poziomie. Polska historia rozwinęła się na gruzach woli. Szlachecka rzeczpospolita była bankructwem rozumu, odstępstwem od twardej woli ekonomicznej i politycznej. Po upadku rzeczypospolitej mamy do czynienia ze stanem rzeczy tragiczniej skomplikowanym. Tradycja polskiego czynnego patriotyzmu zrosła się znowu z formami dziejowego czynu, który polegał na męczeńskim i bohaterskim spalaniu się, nie zaś na konstruowaniu i wznoszeniu. Stąd istnieje straszliwa rozbieżność między metodami myśli działania, prowadzącymi do trwałych wyników w świecie dziejów, a formami myślenia wzruszeniowego, wiążącego nas z narodową tradycją" (Brzozowski 1990: 726). Rozpoznać tę rozbieżność i znieść ją w ruchu nowych całości kultury jest zadaniem myśli niepodległej, wolnej i odpowiedzialnej za los zbiorowy narodu. Dekoratywne baśnie lub 
marzenia, które krzepią serca, owszem, cieszą się chwałą gawiedzi, nie należą wszakże do myśli wolnej. Nie należą do niej także imitacje nihilistyczne, widma radykalizmu, ciągoty zdziecinniałego rozrostu buntu, rewolucji z kompleksów ciągle niedojrzałego rozumu, jakieś testamenty z zasobów i doświadczeń ludzi, którzy nie czują się u siebie, bo stawia się im zadania obrony życia.

Kombinacje uzależnień, hierarchizacji i absolutyzacji poszczególnych całości umożliwiały hierarchizacje cząstkowe, interesu ekonomii nad interesem narodowym i vice versa, religii ponad moralnością, erosu ponad prawem, ponad obyczajem, kultury nad klasą i narodem, wolności ponad interesem, kultury ponad ekonomią, mitologii nad egzystencją społeczną. Terytoria przeciwstawień, ich poszczególnych par, miały swe krystalizacje szczególnie ostre w programach politycznych ruchów socjalistycznych, w których interesy klasowe niweczyły projekty wolnościowe ruchów narodowych irredentystycznego gatunku. Mordercza dla myśli o wolności koncepcja klasy w rozumieniu K. Marksa, wyłożona w głównych jego dziełach i programie komunizmu, znosiła co prawda samą siebie w utopii bezklasowego społeczeństwa, ale wpierw musiała złożyć hołd cnotom walk narodowych w Europie, w tym w Polsce i Irlandii. Potem już nie musiała się hipokrytycznie maskować, gdy ją wzięły na warsztat rewolucje komunistyczne, udane jak w Rosji i nieudane w innych częściach Europy po I wojnie światowej. Jej wyniki teoretyczne ściągały aprobatę grup i środowisk mniejszościowych, dla których emancypacje z ucisku dominujących formacji narodowych lokowały się pojęciowo w ideach wyzwolenia klasowego i równocześnie w rozwiązaniach, w których pomyślność emancypacyjna mniejszości jest identyczna z rozwiązaniem problemu szczęścia ludzkości. Stronników uszczęśliwiania powszechnego przybywało w miarę zróżnicowania społecznego, gdy projekty ich syntez narodowych wlekły się niemiłosiernie w debatach taktycznych, z kim i w jakich sytuacjach historycznych są one osiągalne. Idee rewolucje klasowej miały tedy wzięcie tym bardziej, jeśli dawały natychmiastowe odpowiedzi na dramaty i nędzę masową, znosząc je terrorem bezlitosnym i nieubłaganym dla ich sprawców. Trzeba było tylko znaleźć uzupełnienia i korekty na programach nihilistycznych, które gwałtem wycisnęły swe piętna na ideach powszechnej zmiany. Koncentracja na opozycjach miała sens praktyczny i nie zostawiała wiele miejsca na modele pośrednie. W narastaniu ich napięć, przeciwieństw i zwarcia aspiracje i motywacje łagodzące skutki skrajności uchodziły za wsparcie przeciwników wolności. W lutym 1914 roku Roman Dmowski notowat: „Pod względem dążeń zasadniczych dzisiejsze społeczeństwo polskie coraz wyraźniej rozdziela się na dwa, stojące przeciw sobie obozy: na obóz narodowy, dla którego najwyższą ideą jest dobro narodu, a pierwszym zadaniem politycznym obrona tego dobra na wszelkich stanowiskach i praca nad pomyślnym rozwojem narodu jako spójnej całości moralnej i stojąca przeciw temu obozowi koalicja różnorodnych kierunków, mniej lub więcej świadomie stawiających ponad dobro narodu rozmaite oderwane pryncypia lub interesy partykularne" (Dmowski 2004: VII). Jakoż logika owych rozpadów na obozy przeciwne żywiła każdą ze stron podobną racją eliminacji lub wchłonięcia przeciwnika, przynajmniej na czas walki o dominujące dla siebie cele. Wolność jednej wymaga podporządkowania drugiej i problem jest już tylko taktyczny, jak to zrobić. Atoli mechanizm ten i środki działania są ograniczone dostępem do możliwości pracy przymusu lub okoliczności historycznych, które przygotowują warunki sukcesu jednej ze stron.

Myśl narodowa nie żywi złudzeń, że jej repertuar racji jest wystarczający do czynu historycznie pomyślnego. Musi tedy wchodzić w krytyczne alianse z ową „różnorodnością kierunków”, by własny dyskurs uczynić praktyką politycznie otwartą na krytykę siebie i uzupełnienia z argumentacji mniej zajadłego przeciwnika. Jeśli dobro narodowe jako najwyższy cel ma być historycznie możliwe, nie obejdzie się bez jego określenia w hierarchii wartości głównych. Pewność hierarchii dóbr, za sprawą których naród odzyskuje sam siebie w wolności i niepodległości politycznej, nie może być wystawiona na chwiejne motywacje i tymczasowe debaty taktyczne albo niepowodzenia dyskursywne. Hierarchia dóbr wymaga tedy autorytetu większego niż owo dobro, które ma w niej zająć miejsce naczelne. Autorytet Kościoła łacińskiego spełnia tę rolę. Jest całością społeczno-moralną o historycznie sprawdzonych możliwościach integracji wewnątrz siebie i niesprzecznych ze sobą całości narodowych. Kościół tedy reprezentuje naród w warunkach niewoli w tym, czym jest on w swoich wolnościowych aspiracjach i kulturowych uogólnieniach. „Było to bardziej możliwe, że każdy oddzielny zabór miał tylko jednego metropolitę, który w dużej mierze obok spraw kościelnych reprezentował w pewnej mierze i sprawy narodowe" - zauważa w monumentalnej rozprawie ks. Bolesław Kumor (Kumor 1980: 8). Duża i pewna miara Kościoła katolickiego i spraw narodowych nakładały się na 
siebie, podkreślając, nie zaś znosząc różnice, tym bardziej jak w miarę rozwoju imperiów zaborczych poszczególne kwestie narodowe i religijno-kościelne zyskiwały w nich osobliwość położenia i warunków życia. Synergie kościelno-religijne i narodowe miały silne uzasadnienie tradycją i pewnym przywilejem swobody działania infrastruktur organizacyjnych i kulturowych Kościoła. Aliści, w imperium carskim po powstaniu styczniowym „Kościół rzymskokatolicki również utracił swą względnie uprzywilejowana pozycję. Po 1863 roku setki księży skazano na zesłanie lub uwięzienie, a co najmniej 37 zostało straconych. Do 1870 roku na stanowisku nie pozostał żaden z biskupów, którzy pełnili swą funkcje w 1863 roku. Represje spotkały większość klasztorów i zakonów, a wyświęcenie na księdza wymagało państwowej akceptacji. Cenzorowano listy duszpasterskie i zabroniono podróży za granicę. Biskupom diecezjalnym z dawnego Królestwa Kongresowego zakazano kontaktu z Watykanem inaczej niż za pośrednictwem kongregacji rzymskokatolickiej w Petersburgu. W ostatnich dekadach XIX wieku Kościół nie mógł zaspakajać podstawowych potrzeb religijnych polskich katolików, zwłaszcza w rozwijających się miastach. W polityce dokonał zwrotu od strategii umiarkowanej opozycji i ostrożnej konfrontacji charakterystycznej dla końca lat 50. I początku lat 60. XIX wieku do polityki opartej na strachu i wyrachowanej lojalności" (Snyder 2010: 21). Los arcybiskupa warszawskiego, Zygmunta Szczęsnego Felińskiego zesłanego w 1863 roku na dwadzieścia lat wygnania do Jarosławia nad Wołgą, nieugiętego względem pokus podporządkowania się woli cara, był lekcją Kościoła wyraziście zaangażowanego w pracę nad niepodległością, wolnością Kościoła i narodu. Podczas nieobecności Felińskiego archidiecezją warszawską zarządzali wikariusze generalni: Paweł Rzewuski (1863-1865; zesłany), Józefat Szczygielski (1865-1866; zesłany) Ignacy Domagalski (1866; zesłany). Ich następcom, Stanisławowi Kostce Zwolińskiemu (1866-1872) i Antoniemu Franciszkowi Sotkiewiczowi (1872-1883), udało się. Sprawowali swe powinności kanoniczne, łatając ograniczone funkcje eklezjalne działalnością charytatywną i edukacyjną.

\section{Superstruktura}

Dualizm nowoczesności jest jasny w dystynkcjach, niejasny w ich rozwiązaniach i chronicznie paradoksalny. Paradoks nie nadaje się na uzasadnienie ładu społecznego. Jest rzeczywistością egzystencji bezgranicznie niezadowolonej z siebie, bo w jednej i każdej wersji musi zwalczać swe przeciwieństwo, bez którego żyć nie może. W innej czyni to samo. W każdej inicjuje jakiś wariant samozaprzeczenia. Tylko w jednym zestawie par całości społecznych, mianowicie naród - kościół, samozaprzeczające procesy nie zachodzą w tym czasie w społeczeństwie polskim. Co umożliwia taki wariant współistnienia, co go uprawomocnia, co nadaje rangę w kulturze, organizacji ładu zbiorowego, w myśli o wolności? Wolność właśnie, wartość, cel, zadanie, powinność, obowiązek, struktura czynu zbiorowego. W obu stronach tej pary wolność jest warunkiem istnienia całości społecznej narodu i całości religijnej Kościoła w ruchu nowoczesności. Dualizm jest konieczny i możliwy w pewnych warunkach, gdy struktura społeczna ma charakter konfliktowy, a jej napięcia nie są upośredniczone środowiskami i kategoriami zwolnionymi jakimś habitusem i położeniem stratyfikacyjnym od lojalności względem jednej ze stron biegunowego napięcia. I ten warunek zaszedł w Polsce w drugiej połowie XIX wieku. Pojawił się żywioł inteligencji, fenomen polski, rosyjski i czeski jednocześnie. Jeśli naród jest nowoczesną całością społeczno-kulturową i moralno-społeczną, jest nią za sprawą inteligencji, której pochodzenie ze zdegradowanych środowisk, najczęściej zubożałej szlachty i tracących pozycje zamożnych chłopów oraz aspirujących do wolności mniejszości narodowych, przygotowało do roli liderów w nowych konfiguracjach strukturalnych społeczeństwa polskiego. Nie inaczej wśród Czechów, Niemców i Węgrów w granicach cesarstwa austriackiego, zwłaszcza po zniesieniu absolutystycznych rządów Metternicha w owych, po austriacku idach marcowych 1848 roku, kiedy po likwidacji absolutyzmu otwarły się możliwości nowej konfiguracji politycznej, w której sprawy narodowościowe nabiorą dominującego charakteru, dojrzeją do swego pojęcia. Frantiśek Palacký zdefiniował kwestię narodową dla Czechów w słynnej deklaracji literatów, nauczycieli, ludzi uniwersytetu. Deklaracja z Pragi z 21 marca 1848 roku głosiła równouprawnienie narodów czeskiego i niemieckiego w ramach odnowionej monarchii Habsburgów. Inteligencja Czech miała inny rodowód niż polska czy rosyjska. Jej podstawą było silne mieszczaństwo i bardziej niż w Galicji rozwinięte stosunki kapitalistyczne. W obu strukturach autonomii austriackiej miała do wykonania program odrodzenia narodowego. 
Pojęcia całości społecznych występują w parach nie do rozdzielenia historycznego. Jako pojęcia samowiedzy społecznej, doktryn społecznych, potem główne tematy socjologii narodu (Kurczewska 2002; 1979) żywią w nowoczesności idee niepodległości i wolności. To idee włóczniami ścigane - jak je zwał C.K. Norwid. Obie są wartościami tego samego celu, choć różnego pochodzenia. „Wolność przychodzi jako dar, utrzymuje się poprzez zmaganie” - pisał w poemacie Myślac Ojczyzna Karol Wojtyła. „Całym sobą płacisz za wolność - więc to wolnością nazywaj, że możesz płacąc ciągle na nowo siebie posiadać. Tą zapłatą wchodzimy w historię”. Niepodległość jest formą wolności. Dotyczy wspólnoty, gdy ta jest u siebie, gdy sobą włada. Celem obu jest samostanowienie dobra wspólnego. Jeśli ich brak, wypowiadają się ofiarą swych bohaterów. Także wezwaniem, niejedną jego klęską i powrotem w stronę historii. Lud bez wolności i niepodległości nie ma historii. O Polakach mawiano, że nie mieli XIX wieku - kraj w niewoli, Ubu czyli nigdzie, to znaczy w Polsce. Powrót do historii jest wezwaniem ku niepodległości. „Słaby jest lud, jeśli godzi się ze swoją klęską, gdy zapomina, że został posłany, by czuwać, aż przyjdzie jego godzina”. Nie brakowało tego psalmowego zastanowienia z poematu K. Wojtyły w polskiej drodze do niepodległości. Zapomnienie i czuwanie. Historia jest dziedziną czuwania ludzi wolnych. Niepodległość jest ich zadaniem. Tak się dzieje historia Polski w pewnych szczególnych jej okresie, końca XIX i początku XX wieku. Między wolnością w kulturze i za sprawą kultury, wolnością narodu i za jego sprawą, wolnością Kościoła i gwarancją wolności poprzez Kościół musi wszakże pojawić się coś jeszcze, co łączy je w superstrukturę efektywną historycznie. Co to takiego?

\section{Charyzma i Sacrum}

Czy znoszą one w pojedynkę lub samow tór ostrość dualizmu teoretycznego i metodologicznego koniecznego w teoriach stawania się kultur i całości społecznych? Żadną miarą. Wskazują na fenomen zapośredniczania struktur społecznych i kulturowych, ów mechanizm przystosowywania konfliktu całości do form akceptowalnych, znośnych dla myśli i instytucji ładu zbiorowego. Jako pojęcia nauk społecznych pochodziły z socjologii Emiléa Durkheima (sacrum) i socjologii Maxa Webera (charyzma).

Socjologia Durkheima, posądzana o redukcjonizm w miarę jak antropologia odkrywała jego stronnicze etnograficznie kategorie, ocalała jasnością powiązań tego, co religijne i społeczne. W II połowie XIX wieku nowoczesność ustanowiła epistemologiczne i ontologiczne warunki nauk społecznych. Dwudzielność bytu społecznego ujawniana dogmatem heglowskim w wersji Karola Marksa zdominowała określenia dowolnego zjawiska społecznego. W socjologii, wtedy konstytuującej się jako prawomocna nauka społeczna, kategorie dualizmu ontologicznego weryfikowały się w terminach systematycznego napięcia w strukturach społecznych: kapitał/praca, kapitalizm/feudalizm, miasto/wieś, władza/podporządkowanie, kultura/ekonomia, kultura/ przyroda, klasa/naród, państwo/obywatel. Ani jeden składnik dowolnego zbioru społecznego, któremu udało się znaleźć strukturalne usytuowanie, nie mógł się urzeczywistniać poza swoim przeciwieństwem. Prymitywna i wyrafinowana dialektyka bytu tłumaczyła zjawiska i procesy, a dodatkowo wkomponowane w dynamikę ewolucjonizmu darwinowskiego uzyskiwały horyzont historycznych przekształceń o regularnych kształtach. Jeśli coś jest strukturalne, musi wskazywać na stabilność przeciwieństw i ich znoszenie się w jakimś ruchu historycznie doniosłym, którego źródła nigdy nie wygasają, jeśli ład zbiorowy ma mieć charakterystykę strukturalną. Istnienie pozastrukturalne jest nie do pojęcia tak samo jak istnienie pozahistoryczne. Socjologia Durkheima postawiła tej nauce poważne zadanie i wyzwanie: jak możliwe są społeczeństwa, historycznie trwałe, które swoje przekształcenia zawdzięczają nie przemocy, do której wzywa dwudzielność biegunowa strukturalnego typu, ale solidarność organiczna i solidarność mechaniczna, czyli takie typy więzi społecznych, w których mechanizm przekształceń polega na kooperacjach, zasadzie wzajemności, funkcjonalnej odpowiedniości myślenia i działania społecznego, świadomości, wyobraźni, przedstawień zbiorowych i ich podstaw w rzeczywistych procesach kształtowaniu struktur społecznych. Pięćdziesiąt lat później zradykalizuje te aporie filozofia Emmanuela Lévinasa, w której Catość i nieskończoność dociera do źródłowych kwalifikacji życia człowieka i konsekwentnie paradoksalizuje wszelkie idee całości (Lévinas 1998). W socjologii Durkheima paradoks całości dopiero przeciera szlaki. Równocześnie w badaniach religii socjologia ta przyjęła z ducha to samo stanowisko paradoksalizujące, by wszystkie jej przejawy i efekty reprezentowały funkcjonalny odpowiednik jakiejś formy więzi społecznych. Jeśli socjologia miała być nauką, musiała konsekwentnie wszelkie 
swe przedmioty, nie wyłączając religii, sytuować w polu społecznych zależności. Religia jest paradoksją i jej reprezentacją nieusuwalną z dowolnej struktury społecznej, z dowolnej zbiorowości, która już uchwyciła siebie w terminach całościującej wiedzy o sobie. Idzie tylko o to, czego ona jest reprezentacją, jakiego źródła strukturalnie trwałego jest zjawiskiem. Religia jest reprezentacją strukturalnej istoty wszelkich form uspołeczniania relacji, odziaływań i zależności w zbiorowości ludzi o trwałych, stabilnych w niej typach więzi. Nie jest przedmiotem socjologii lub w ogólności nauk społecznych, jeśli jest ujmowana w terminach opozycji świat nadprzyrodzony - świat przyrodzony, bo sama opozycja nadnatury i natury jest już faktem społecznym określonej genezy i historycznej regularności przejawów. Socjologia Durkheima jest gruntowną nauką społeczną, to znaczy cokolwiek jest rzeczywiste społecznie, należy do formy zjawiska na istocie relacji i zależności w danej zbiorowości. „Chociaż powszechnie czytany - zauważa Eric Sharpe - Durkheim był tak opętany chęcią wyjaśnienia fenomenu religii, że jego teorie o pochodzeniu religii są mało istotne. Konsekwencje Jego odrzucenia wiary ludzkości w faktyczne istnienie niewidzialnego nadprzyrodzonego porządku - odrzucenia, w którym miał mieć wielu naśladowców - doprowadziły go do poważnych błędów interpretacyjnych. Badacz religii w ujęciu porównawczym może go czytać nie tyle, aby zdobyć wiedzę o naturze religii, albo o drażliwym problemie pochodzenia religii, ile raczej by dowiedzieć się czegoś o pozycji tych teorii we Francji przełomu XIX i XX wieku” (Sharpe 1986: 86).

W tym samym czasie teoria społeczna zaczęła zyskiwać na znaczeniu. Dodajmy, Durkheim był powszechnie czytany, ale nie w ówczesnej Polsce. Dopiero za sprawą Stefana Czarnowskiego, ucznia Durkheima, czyli w II Rzeczypospolitej, socjologia Durkheima osiągnęła autorytet właściwy paradygmatycznym stanowiskom w nauce uniwersyteckiej. Bolesław Limanowski, autor Wstępu do socjologii z 1900 roku, w trzecim wydaniu tego podręcznika zatytułowanego Socjologia (1921), odnosi się do prac Durkheima, Les règles de la mèthode sociologique (Zasady metody socjologicznej), z wydania z 1912 roku (Limanowski 1921: 43), i do De la division du traval social (O podziale pracy społecznej) z wydania z 1902 roku (Limanowski 1921: 151). Znaczenie Durkheima narastało w następnych dziesiątkach lat, by w latach sześćdziesiątych XX wieku wywołać prawdziwy ruch neodurkheimowski. Mary Douglas, Victor Turner, Peter Berger, Luis Dummont, Cliford Geertz, Robert Bellah, Claude Lévi-Strauss, każdy z nich miał udział w odkrywaniu perspektywy durkheimowskiej w teoriach religii, kiedy już nie musiały one sytuować się po stronnie którejś z opozycji nadnatura/natura, struktura/historia, kultura/przyroda, całość/część. Opozycje te zostały - by tak rzec - uspołecznione i zantropologizowane. Elementarne formy życia religijnego Durkheima, dzieło z 1912 roku (Durkheim 1990), tłumaczyły je w terminach systemów klasyfikacji społecznych w danej kulturze i w terminach socjologii wiedzy swoiście durkheimowskiej, to znaczy w świetle założenia, że podstawowe (ogólne) idee w nauce, moralności, obyczaju, prawie, religii, słowem - w kulturze są funkcją struktury społecznej i jej zmian. Sposób, w jaki ludzie łączą się bądź rozdzielają, tworzy kategorie, przez które przefiltrowane są wszystkie inne doświadczenia i ich ujęcia poznawcze. Kluczowym aspektem świata materialnego jest samo społeczeństwo. Rytuały są mechanizmem, który produkuje idee o znaczeniu społecznym, a treść idei odzwierciedla strukturę społeczeństwa. Durkheim przyznał, że idee po ich uformowaniu mają częściową autonomię. Jonathan Z. Smith, w krytycznej kontynuacji perspektywy durkheimowskiej (Smith 1979; 1987; 2005), wykazuje, że jej doniosłość nie polega jedynie na tym, że ustanawia teorie socjologiczną w ścisłym sensie tego słowa, a na tym raczej, że w okresie agresywnego sekularyzmu i jego odkryć w funkcji prawomocności nowoczesności (Blumenberg 2019) jej kategorie nie są lekceważąco antyreligijne bądź obraźliwie redukcyjne w stylu debat radykalizmów przełomu XIX i XX wieku. Z akademickiego punktu widzenia pytanie o ostateczne odniesienie religii mogło tedy być odroczone i wzięte w nawias, zaś społeczna konstrukcja religii mogła pojawić się w studiach fenomenologii, jej matryc, na których zbudowano potem studia szczegółowe (Tarkowska 1990: XV). Durkheim więc przygotował nowe spojrzenie na religię znoszące racjonalistyczny dogmat ich iluzyjnego źródła. Motyw ten uwydatnia Karin Fields we wprowadzeniu do tłumaczenia książki Durkheima na angielski z 1995 roku, uznając, że podstawowa durkheimowska teza o społecznej konfiguracji religii nie jest redukcją religii do społeczeństwa, ale szczególnym rozszerzeniem pojęcia społeczeństwa, które skupia wewnętrzną istotą każdej religii i włącza ów moment jej sui generis struktury oraz funkcję pojęcia sacrum (Fields 1995: XVIII). W tym sensie religia jest redukcją taką samą jak nauka. Bo wszelka myśl i interpretacja, religijna czy naukowa, jest z konieczności redukcyjna. Wybierając niektóre cechy świata do celów analizy, pomija inne. Sacrum jest reprezentacją 
istoty społeczeństwa. Istota społeczna wyłania i reprezentuje się w rozmaitych swych przejawach dlatego, że każdorazowo należy do całości społecznej. Holizm Durkheima operuje realistycznym pojęciem całości społecznej. „Świętość”, jej sakralizujące procesy i realizacje poszczególne uaktywniają się wszędzie tam, gdzie pojawia się problem tożsamości grupowej całości społecznej, gdzie jej waga społeczna rozstrzyga o wartościach głównych, o autonomii narodu w relacjach z innym formami grupowania, z innymi formami całości społecznej. Jej zasoby symboliczne dochodzą do głosu w odpowiedziach na pytania o lojalność plemienną, sekciarką czy o status praw człowieka, w wojnach kulturowych o nienaruszalność życia od poczęcia, o status małżeństwa i rodziny, klasyfikacji genderowych. W tym, co „święte”, zawsze chodzi o całość społeczną. Gdy poststrukturalistyczna myśl społeczna próbuje zamienić typ idealny i język wzorów uniwersalnych „świętości”, zwracając uwagę na mikrospołeczne zachowania strukturujące habitusy, gdy role międzykulturowego modelowania społecznych relacji i zachowań nie przestają judzić w polu wartości, likwidując ich znaczenia, „świętość” całości odzywa się mocą grupowych tożsamości, poza którymi żadna ustrukturalizowana zbiorowość nie ma warunków identyfikacji siebie jako wartości. Że sacrum jest społeczne, nie podlega dyskusji. Że jest reprezentacją bezkonkurencyjną istoty danej całości, trzeba dowodzić praktycznie z dowolnego i każdego poziomu jej struktury, od mikro - rodzina, do globalnej - społeczeństwa w swych historycznych uporządkowaniach narodowych. To jest ów moment historyczny każdej formy sacrum, z wnętrza której pochodzi jej odniesienie do swego przeciwieństwa, do profanum. Profanum ma inny status niż sacrum. Profanum jest znaczone, sacrum jest znaczące. Powiązania między nimi są kategoryzowane społecznie i historycznie. W jaki sposób naród, jako dziedzina profanum, rozpoznaje się poprzez znaczące, historyczne sacrum? Przez religię - na przykład chrześcijaństwo, jeśli ma ono wyznaniowe, kościelne granice, przez katolicki Kościół albo prawosławne formy eklezjalne. Wielkie podziały kulturowe Europy zawierały kryteria eklezjalne: łaciński Zachód, prawosławny Wschód. Katolicyzm - jeśli ma on zróżnicowane formy przedstawień zbiorowych, czyli reprezentacji symbolicznych, wchłania heterogenię swego narodowego substratu. Idzie o reprezentacje momentu całości w historycznym ruchu jej struktury.

Całość społeczna narodu, jej spójność kulturowa i moralna, jeśli jest heterogeniczna pod dowolnym względem, odnajdzie się w religiach obywatelskich. Ich sacrum nadaje władzy autorytet i bywa jej postulatem, stygmatem ruchu jej powołania, inicjacji panowania, rytuałem w chwilach kryzysu, epitomem w momentach dekadencji. We wszystkich jest kapitałem z symbolizmu jej historycznego znaczenia, uprawomocnieniem i przeniesieniem jej struktury na poziom wspólnoty. Wyobrażenia, przedstawienia zbiorowe sacrum są warunkiem efektywności całości jako wartości. Sacrum umożliwia akcje przeniesienia doświadczenia całości na poziom wspólnoty. Społeczeństwo (całość) i wspólnota to rzeczywiste procesy nieustannej wymiany symbolicznej, które kontrolują poszczególne procesy i kategorie tożsamości społecznej. Poza nimi ani jednostka, ani grupa nie mają narzędzi określania siebie na podstawowych relacjach i zależnościach. Wspólnota jest reprezentacją momentu całości w zbiorowości, która może kontrolować siebie samą, utożsamiać moment ogólności, swój typ dziejowy - jak by napisał Stanisław Brzozowski, z akcją kultury tu i teraz. Zadaniem sacrum jest integracja wspólnoty z całością społeczną. Sacrum indywidualizuje całość, partykularyzuje jej wartości i znaczenia, umożliwia symboliczny dostęp do całości poszczególnym grupom i osobom i przez nie czyni je reprezentantami siebie. Całość jest obecna w każdym, kto jest sługą sacrum. Sacrum stanowi uniwersum znaczeń, których użycie obiektywizuje całość na poziomie jednostki. Co, jeśli całość uzurpatorsko zawłaszcza uniwersum znaczeń i przygotowuje sacrum do służby w jej imieniu? Idolatrie totalistyczne. Naród, rasa, klasa czy państwo w praktykach idolatrii zstępują sacrum jego kompletnym zawłaszczeniem i zniszczeniem. Idolatrie totalistyczne muszą niszczyć religie i siebie ustanawiać jej centrum kultowym. Jej historyczne realizacje w niemieckiej kulturze doprowadziły do usankcjonowania mordu w operacjach Judeocydu, w operacjach komunizmu do usankcjonowania likwidacji wszystkiego, co samodzielne. Idolatria totalistyczna jest - z punktu widzenia Kościoła - herezją. Pytała o to Edyta Stein w liście do Piusa XI: „Nie jest może jawną herezją idolatria rasy i władzy państwowej...?” (Stein 2002: 458). Całości idolatryczne są totalistyczne w tendencji głównej. Tak aktywizują się jej rozmaite epitomy symboliczne Gott mit uns, serie sakralizacji hymnologicznej, psalmodia w kulcie narodu jako wartości bezwzględnej, świętej. Sacrum idolatryczne musi być zazdrosne, a sacrum narodowe, państwowe czy klasowe - dodatkowo ofiarożercze. Przeciwko sobie ma sacrum Kościoła, chrześcijaństwo antyidolatryczne, mowę - względem siebie - cudzych 
bogów. Religia jest faktem społecznym sui generis. Nie tylko w tym jej znaczenie. W tym przede wszystkim, że do całości społecznej należy, nań wskazuje, że jest jej niekonkurencyjną reprezentacją symboliczną, fundamentalnie inaczej niż sztuka, nauka, obyczaj, prawo itp. Społeczeństwo niereligijne jest absurdem, choć są - rzecz prosta - ludzie niereligijni, to znaczy bez świadomości religijnej określonego typu. Gdy zachodzi jakiś kryzys w idei i doświadczeniu całości społecznej, pojawia się charyzma, korekta w funkcjach sacrum, przywołanie go do porządku, forma sacrum wyjątkowego w obiektywizacji osobowej i rutynowego w obiektywizacji rzeczowej, instytucjonalnej, urzędowej.

\section{Charyzma}

Sacrum wyjątkowe odnawia całość społeczną, inicjuje ją albo rekonstruuje. Identyfikuje, nazywa, ożywia całościujące podstawy wspólnoty. Całość potrzebuje charyzmy w warunkach kryzysu wartości podstawowych. Charyzma przemawia tylko wtedy, kiedy całość jako pojęcie, idea, doświadczenie, rutyna, kategoria poznawcza, rytuał, instytucja, moment świadomości społecznej traci żywotność. Kiedy relacje między wspólnotą a całością społeczną danego typu, narodu, klasy, państwa, kultury przestają działać, a czynniki dyssypatywne są silniejsze niż czynniki integracyjne, charyzma jest ruchem odnowicielskim procesów integracyjnych. Jej duch tchnie kędy chce. A chce wtedy, kiedy rutyna integracyjna wyczerpuje swe możliwości. Charyzma jest zjawiskiem na sacrum. Jest instrumentem zapośredniczenia formy sakralnej i formy całości społecznej. Jest stale pomiędzy nimi i dopóki jest, naród ma kapitały kulturowe swej tożsamości. Gdy jej brakuje, zbiorowość kreuje jej zastępcze analogie. Jako pojęcie charyzma należy do słownika socjologii Maksa Webera.

Może przysługiwać ludziom i przedmiotom, miejscom, formom, ikonom, jeśli wskazuje na swe moce z pochodzenia nadnaturalnego, ponadludzkiego. Charyzma demonstruje jakąś władzę, zdolność bezwarunkowego działania w swoich kontekstach. Jako kategoria socjologiczna jest typem idealnym, to znaczy pojęciem, które może być stosowane w socjologicznych rekonstrukcjach zdarzeń, struktur, form, faktów i procesów z zakresów jakiejś władzy. Jest typem idealnym jak pojęcie całości społecznej. Socjologia Maksa Webera dysponuje kategoriami całości tylko w granicach umożliwionych ich typem idealnym. Całość społeczna w socjologii Durkheima jest bytem społecznego realizmu ontologicznego. W ujęciach Maksa Webera jest postulatem metodologicznym. Holizm metodologiczny w terminach typów idealnych pozwala na zbadanie zależności i uwarunkowań wielkich całości społecznych, ekonomicznych i kulturowych z wzajemnością ich oddziaływań. Etyka protestancka i duch kapitalizmu, dzieło z lat 1904-1905, dowodzi efektów zastosowania metodologii typów idealnych w sposób umożliwiający wyjaśnianie obu stron historycznej zależności. Nieuchronność kapitalizmu wymagała pewnej wewnętrznej siły etosu moralnego, to znaczy czynnika, bez którego „nieuchronność” właśnie jest przypadkiem historycznym, nie zaś losem. Ów etos protestancki był warunkiem przezwyciężania tradycjonalizmu, głównego oponenta kapitalizmu. Tradycjonalizm poniekąd jest właściwy społecznej naturze ludzkiej. Jego korzyści gwarantują spokój i ciągłość, równowagę, harmonię, dopóki nie zderzy się z redukcją zasobów ekonomicznych, które je warunkują. To właśnie następuje regularnie, gdy naturalne zasoby się wyczerpują, a tradycyjne formy ekonomii nie gwarantują już realizacji typowych potrzeb społecznych wymaganych przez zasady ciągłości, reprodukcji, integracji społecznych. Purytanizm i etyka protestancka były czynnikami uwalniającymi zagrożenia tradycjonalizmu poprzez idee i wzory metodycznej pracy, powstrzymywanie konsumpcji, ascetyzm. Problem purytańskich źródeł zachodniego kapitalizmu inspirował studia nad związkami typów całości kulturowego rozwoju w skalach globalnych historycznie i terytorialnie oraz nad organizacją strukturalną życia społecznego (Weber 2000). Tymi studiami, jak wiadomo, unieśmiertelnił Weber kanon socjologii religii, socjologię typów idealnych, socjologię interpretatywną (rozumiejąca). Publikując pierwsze z nich, Religię Chin, Weber zamierzał upowszechnić je razem z Wirtschaft und Gesellschaft (Weber 2002). Podobnie przepracowując tekst Etyki protestanckiej... w 1919 roku do zbioru prac z socjologii religii, dodawał, że materiały ze studiów etnograficznych będą stale uzupełniały typowe zagadnienia socjologii religii. Otóż i to: religia należy do podstawowych problemów socjologii i żadna systematyka socjologiczna obejść się bez niej nie może. Co jednak, gdy jej formy i funkcje ulegają, bywa, szybkim zmianom? Pojawia się problem „odczarowania”. Nowoczesność odczarowuje światy społeczne. Pojęcie odczarowania znalazło zastosowanie w 1913 roku, w studium wyjaśniającym podstawy weberowskiej 
teorii działania społecznego pt. Niektóre kategorie socjologii rozumiejącej. Opracowanie powstawało równolegle z badaniami obejmującymi kwestie Religijnych wspólnot, włączone do licznych wydań prac zebranych z socjologii religii (Weber 2002: 318-482). Podług tych studiów tylko rzeczy, wydarzenia, które rzeczywiście istnieją lub właśnie zachodzą, odgrywają jakąś rolę w życiu zbiorowym. Jednak sytuacja zmienia się wraz z pojawieniem się magii. Ale w niej zachodzi w nowoczesności proces przekształcania z form bezpośredniej manipulacji siłami zewnętrznymi w formy symboliczne. Wynikiem tego procesu jest intelektualizm i racjonalizm, które redukują wiarę w magię. Cały świat odczarowuje się, traci swe dotychczasowe znaczenia. Owszem, jakieś ich pozostałości się odnawiają, zdarzają się, bez możliwości uogólniania. W ten sposób podzielony świat znaczeń przeniósł swoiste konstrukcje religijne do rzeczywistości, które działają wedle swych własnych regularności. To właśnie ten proces, zdaniem Webera, pozbawił świat nieodłącznych znaczeń i ostatecznie przekształcił religię w odrębną, własną sferę. Wzajemna więź religii i modernizacji konfiguruje poszczególne formy całości w danej dziedzinie działania społecznego, w religii i strukturze społecznej w sposób wyróżniający procesy odczarowania. Są one odmienne niż zjawiska sekularyzacji. Te dotyczą głównie rozmaitości prawa, prawomocności, prawowitości, procesów legitymizacji. Pojęcie odczarowania nie oznacza dewastacji religii, raczej jej przekształcenia sui generis, na własnych prawach. Oznacza nieuniknione doświadczenie świata pozbawionego znaczenia. Gdy zachodzi w stopniu umożliwiającym działania emancypacyjne, mają miejsce liczne zróżnicowania religijne łącznie z przeniesieniem znaczeń ze sfer zobiektywizowanych, instytucjonalnych, w pełni opierzonych form kościelno-kongregacjonistycznych do form indywidualizacji i prywatyzacji religii. Religia instytucjonalna ustępuje religijności indywidualnej. Jednym z efektów tego procesu jest rozrost form ezoterycznych i apokaliptycznych, które w połączeniu z rzeczywistym i wyimaginowanym poczuciem zagrożenia, na przykład związanego z pandemiami, wracają do podstaw tworzenia się nowych całości kulturalnych. W tych warunkach charyzma musi się pojawiać regularnie, jeśli realne całości społeczne mają zachowywać się efektywnie i projektować źródła ocaleń jednostek i grup. Jej typy osobowe, od mesjasza, proroka, innowatora, kapłana, reformatora, każdorazowo inicjują podstawy trwałości ładu zbiorowego, przywracają mu akceptację, żywotność, aspiracje, legitymizację, wartość w działaniu społecznym. Charyzma wyznacza lidera. Lider wyznacza reguły działania. Domaga się posłuszeństwa, ustanawia standardy, w szczególności prawo. Oferuje wzory życia, upowszechnia prawdy albo objawienia. Jest ich niezastąpionym interpretatorem. Autorytet charyzmy odsłania się nie tyle w świetle jakiejś tradycji lub racjonalności, ile w doświadczeniu jakiegoś radykalizmu. Legitymizacja całości społecznych nie może się obyć bez jakiegoś osobowego typu charyzmy. Gdy ich brak, całości społeczne martwieją. Zostają na poziomie administracji z naturalnym w tych warunkiem rozrostem biurokratyzacji. Biurokratyzacja, powiada Weber, zabija kapitalizm współczesny tak samo, jak niegdyś uczyniła to w starożytności (Weber 1976: 277-278). Duch racjonalizmu zapoczątkowany przez ascetyzm osiągnął własny rozpęd, a w kapitalizmie porządek racjonalistyczny stał się żelazną klatką, w której ludzkość, z wyjątkiem możliwości proroczego odrodzenia charyzmatycznego, została uwięziona być może do czasu, kiedy ostatnia tona węgla zostanie spalona. Obserwacja Webera z 1909 roku daje się powtórzyć, jeśli uwzględnić zaawansowane procesy nowoczesnego korporacjonizmu: konfrontacja z hegemonią narastającego korporacjonizmu niewiele zostawia miejsca dla wolności, w każdym tego pojęcia znaczeniu. Charyzma niekorporacjonalistycznych form całości społecznych, narodu w szczególności, ocala wolność, liczne zjawiska społeczne w tych zakresach, w których liczy się tożsamość społeczna. Jeśli charyzma przemawia wzorami religii odczarowanych, odkrywa nieuchronne napięcia między autonomizacją ekonomii, polityki, kultury, seksualnością i stara się je uporządkować, usystematyzować w nowych granicach nowych całości, jeśli te mają jeszcze jakiś wigor. Napięcia te w dziedzinach religii prowadzą do ich względnej autonomizacji, w formacjach zaś kongregacjonalistycznych i kościelnych do ich sinusoidalnej charakterystyki znaczenia. Raz pojawią się jako tendencja do znaczenia megakościołów - bo tylko takie stać na rekonstrukcje charyzmatyczne całości społecznych, innym razem w wersji tzw. kościołów otwartych zmagających się z problematem własnej tożsamości, czyli faktycznie z redukcją siebie do wymagań i przemocy swego otoczenia. Zaiste, los kalwińskich ugrupowań, także formacji luterańskich opisuje konsekwencje poddania się standardom systematycznej adaptacji do presji zewnętrznych z anihilującymi skutkami w centrum ich organizacji, zaś programy religijności zindywidualizowanej w tych samych okolicznościach muszą praktykować doktryny ucieczki przed światem, swoistej izolacji, która jest jedynym narzędziem obrony przed 
nieustępliwością grzesznego świata. Seksualność i sztuka działa w tych warunkach autonomizacji ich znaczeń mocą paradoksu: rewitalizują zaczarowane ich formy. Przyznając sobie bezgraniczną swobodę uznają, że są odpowiedzią na wszystko. Typowy to mechanizm zaczarowywania, spod którego żądają uwolnienia. Aliści to przypadek socjologicznie już sprawdzony. Jeśli całości społeczne tracą na znaczeniach, formy i działania, które mają je zastąpić, demonstrują najgorsze własności zwalczanych zależności: przemoc.

\section{Konkluzje. Idea całości w debacie o realizm w socjologii}

Pojęcia całości społecznej fundowały podstawy socjologii i pytania o ontologię rzeczywistości, którą opisują. W szczególności miały one i nadal mają udział w kształtowaniu dyskursu teoretycznego nauk społecznych. Od początku ich systematyzacji, od czasu dyskusji z przełomu XIX i XX wieku o statusie naukowym socjologii, uzasadnienie wiedzy socjologicznej domagało się przygotowania filozoficznego, odpowiedzi na pytanie, czym jest jej przedmiot jako struktura ontologiczna. W reakcjach na postpozytywizm koncepcje realizmu ontologicznego całości społecznej równocześnie były krytyką relatywizmu, solipsyzmu, nihilizmu poznawczego, owej próżni pozostawionej przez załamanie się pozytywistycznej filozofii. Że całościom społecznym przysługuje realne istnienie poza świadomością obserwatora i uczestnika, taka teza nie miała niekontrowersyjnego dowodu. Owszem, wskazywała na szczególne warunki i założenia swej oczywistości. Jej alternatywa w postaci koncepcji interpretywizmu miała w tej kwestii sporo do pokazania. Realizm i interpretywizm konkurują w socjologii od czasu Methodenstreit, owej debaty, początkowo w granicach niemieckiej historiografii, potem w ekonomii i naukach społecznych od 1871 roku do połowy wieku XX. Pytanie o status ontologiczny całości społecznych nadawał jej charakter osi epistemologicznej. Reartykulacja tamtych dyskusji pojawiła się w drugiej połowie tego wieku, gdy niepewność wyników badań socjologicznych, ich chronicznie tymczasowy charakter miał je dyskwalifikować i usuwać z nauki. Czy nauki społeczne mają usprawiedliwione racje, by zachować naturalistyczne ambicje, czy inaczej, ograniczyć się do bardziej humanistycznego podejścia jak w naukach o kulturze? Pytania o naukowy status socjologii odświeżały zagadnienia początków socjologii. Jeśli bowiem nie jest ona nauką, to czym jest? Epistemologiczny dyskurs realizmu wyznaczył generacyjną wartość teorii socjologicznej w drugiej połowie wieku XX. Potem chodziło już o szczegóły. Interpretywizm nie miał w swej historii tak gorączkowych debat. Miał jednak nie byle jakich ojców założycieli: Maksa Webera, Georga Simmela czy Wilhelma Diltheya, i doniosłe wyniki, zwłaszcza jak porzucił albo przezwyciężył ortodoksyjny konsensus powiązany z cenionymi akcjami kulturowego zwrotu z lat sześćdziesiątych ubiegłego wieku. W filozofii nauki realizm jest reakcją na postkuhniański kryzys naukowej racjonalności, pewien sposób konceptualizacji empirycznej odpowiedzialności i serie przyczynowych twierdzeń nauk przyrodniczych poza pozytywizmem. W socjologii wszakże miał on dwie spójne i dobrze identyfikowalne wersje: ścisłą (Bhaskar 1979; 1994) i refleksywną (Archer 2019; 2013; 1995). Pierwsza proponowała jasną i wyraźną opcję socjologicznego naturalizmu postulującą unifikację teoretyczną, testowalność hipotez i zdolność wyjaśniania za pomocą uniwersalnych mechanizmów całości i procesów społecznych oraz ich korelatów. Druga mediatyzowała naturalizm poprzez historycznie aktywne, względnie trwałe fakty i procesy, w których odzwierciedlały się główne troski społeczne w postaci ideologii, koncepcji działania, historycznych trajektorii procesów zachodniej nowoczesności. Refleksywny realizm optował i nadal to czyni za historyczną koncepcją mechanizmów społecznych, uwzględniając rolę wiedzy konstytuującej społeczne całości strukturalne. Realizm ścisły postuluje w zakresie mechanizmów procesów, struktur i zachowań zasadę transcendencji, silną ontologię; refleksywny - zasady historycznego i terytorialnego (geograficznego) zróżnicowania; w zakresie roli ideologii, wiedzy, dyskursu realizm ścisły uwzględnia przekonania i preferencje podmiotów działania, realizm refleksywny zaś częściowo konstytutywną strukturę społeczną. W zakresie celów teorii społecznej realizm ścisły akcentuje nade wszystko ontologię społeczną, podobnie jak realizm refleksywny. W zakresie wyjaśniania realizm ścisły jest dedukcyjny, obstaje przy regułach testowalności hipotez. W tej sprawie realizm refleksywny głosi powiązania teorii z indukcyjną zasadą badań historycznych (Sewell 1980; 1992).

Pytania o ontologiczny realizm całości społecznych angażują elementarne warunki uprawiania socjologii, jej pragmatycznej efektywności. W wersji realizmu refleksywnego odpowiedzi na nie ostatecznie uwalniają spod presji pozytywistycznych pewne trudności naturalizmu, które jeszcze drążą realizm ścisły. By skorzystać 
z opinii Steinmetza, refleksywny realizm umożliwia stronnikom teorii kulturowych i złożonych form wyjaśniania obronę ich samych przed wrzuceniem do worka niezróżnicowanych kategorii postmodernizmu i eklektyzmu, równocześnie odnawiając więzi z hermeneutyką i poststrukturalizmem (Steinmetz 1998: 183). Okoliczność ta upodabnia jego epistemologiczne reguły do interpretywizmu, nie znosząc wtórnych odmienności. Obie koncepcje wiedzy socjologicznej odrzucają empirystyczną ortodoksję, że obserwowalne zmienne i wydarzenia, ich powiązania są wystarczającym warunkiem wglądu w naturę świata natury bądź światów społecznych. Raczej nalegają na możliwość ich zrozumienia poza domniemaniem metod indukcyjnych. Warunkiem wyjaśniania socjologicznego jest każdorazowo wykroczenie poza i ponad serie obserwacji, to znaczy wywnioskowania z tego, co jest obserwowane i rejestrowane jako fakt, by on sam stał się składnikiem całości, ze względu na którą w ogóle zachodzi. Realizm refleksywny i interpretywizm - jak zauważa Isaac Reed - „opierają się ponadto na teorii społecznej, aby dokonać skoku poza to, co empiryczne, do tego co umożliwia nam wyjaśnienie działań społecznych. Realizm, jak i interpretywizm są epistemologiami głębokimi, odrzucającymi zarówno pozytywistyczne, jak i współczesne spory, że interpretacja poza powierzchnią życia społecznego jest metafizyczną bzdurą" (Reed 2008: 124).

Idea całości społecznych ma tedy silne zakorzenienie w dziejach socjologii, w formacjach kultury, w ruchach dyskursu społecznego, w praktyce politycznej i jej doświadczeniach zbiorowych. Koniec wieku XIX i początek wieku XX były dekadencją i rozwojem równocześnie nowych całości społecznych oraz ich nowych idei. Historyczne ich konstrukcje ustanowiły w Europie, zwłaszcza po rozpadzie miłego świata imperiów, które same jako idee ostały się jedynie w nostalgii i lamentacjach, nowe konfiguracje holistyczne. W ich granicach całości narodu, kultury, religii miały odegrać rolę główną. Światy społeczne są zrozumiałe wewnątrz konturów swych całości.

\section{Bibliografia}

Abrutyn S. (2009), Toward a General Theory of Institutional Autonomy, „Sociological Theory”, vol. 27(3), s. 449-465. Adorno T. (1986), Dialektyka negatywna, tłu. K. Krzemieniowa. Warszawa: PWN.

Adorno T. (1994), Dialektyka oświecenia. Fragmenty filozoficzne (z Maxem Horkheimerem), wyd. I, tłum. M. Łukasiewicz. Warszawa: Wydawnictwo IFiS PAN, s. 449-465.

Archer S.M. (2019), Kultura i sprawczość, tłum. P. Tomanek. Warszawa: Narodowe Centrum Kultury.

Archer S.M. (2010), Routine, Reflexivity and Realism, „Sociological Theory”, vol. 28(3), s. 272-303.

Archer S.M. (2013), Cztowieczeństwo. Problem sprawstwa, tłum. A. Dziuban. Kraków: Zakład Wydawniczy NOMOS. Archer S.M. (1995), Realist Social Theory: The Morphogenetic Approach: Cambridge University Press.

Arendt H. (1983), Korzenie totalitaryzmu, tłum. M. Szawiel i D. Grinberg. Warszawa: Niezależna Oficyna Wydawnicza. Berlin I. (1994), Cztery eseje o wolności, tłum. H. Bartoszewicz, D. Grynberg, D. Lachowska, A. Tanalska-Dulęba. Warszawa: PWN.

Bhaskar R. (1979), The Possibility of Naturalism. New York: Harvester Press.

Bhaskar R. (1994), Plato, Etc. The Problems of Philosophy and their Resolution. New York: Verso.

Blumenberg H. (2019), Prawowitość epoki nowożtnej, tłum. T. Zatorski. Warszawa: PWN.

Brzozowski S. (1973), Kultura i życie. Warszawa: PIW.

Brzozowski S. (1979), Sam wśród ludzi. Wrocław - Warszawa - Kraków - Gdańsk: Zakład Narodowy im. Ossolińskich. Brzozowski S. (1990), Legenda Mtodej Polski [w:] Eseje i studia o literaturze, t. II. Wrocław - Kraków - Gdańsk - Łódź:

Zakład Narodowy im. Ossolińskich.

Brzozowski S. (1997), Ptomienie. Warszawa: PIW.

Brzozowski S. (2007), Pamiętnik. Wrocław - Warszawa - Kraków, Zakład Narodowy im. Ossolińskich.

Cywiński B. (2010), Rodowody niepokornych. Warszawa: Literatura Faktu PWN.

Cywiński B. (bdw), Dzieje narodów Europy Wschodniej. Editions Spotkania, wyd. II, bmw.

Dmowski R. (1990), Myśli nowoczesnego Polaka [w:] Wybór pism. Warszawa: PIW.

Dmowski R. (2004), Upadek myśli konserwatywnej w Polsce. Wrocław: Wydawnictwo „NORTOM”.

Dmowski R. (2014), Kościót, Naród i Państwo [w:] Wybór pism, t. I. Poznań: Zysk-i S-ka, s. 755-782. 
Durkheim É. (1990), Elementarne formy życia religijnego, tłum. A. Zadrożyńska, wstęp i red. nauk. E. Tarkowska. Warszawa: PWN.

Hamelin A.-M., OFM, (1966/7), Zasada catości (Principe de Totalite) i swoboda rosporządzania sobą, „Concilium. Międzynarodowy Przegląd Teologiczny”. Poznań-Warszawa: Pallotinum, s. 202-210.

Hesse H. (1999), Gra szklanych paciorków, tłum. M. Kurecka. Warszawa: PIW.

Fromm E. (1997), Ucieczka od wolności, tłum. O. i A. Ziemilscy. Warszawa: Czytelnik.

Jabłońska-Deptuła E. (1983), Przystosowanie i opór. Zakony męskie w Królestwie Kongresowym. Warszawa: PAX.

Jan Paweł II (1990), W imię przysztości kultury. Przemówienie Ojca Świętego. Poznań.

Kumor B. (1980), Ustrój i organizacja Kościoła polskiego w okresie niewoli narodowej 1772-1918. Kraków: Polskie Towarzystwo Teologiczne.

Kurczewska J. (1979), Naród w socjologii i ideologii polskiej, Warszawa: PWN.

Kurczewska J. (2002), Naród w socjologii polskiej. Od Józefa Supińskiego do Aleksandra Hertza [w:] Dusza spoteczeństwa.

Naród w polskiej myśli socjologicznej, wybór tekstów pod red. J. Kurczewskiej. Warszawa: Narodowe Centrum Kultury.

Lachowska D. (2002), Wstęp [w:] M. Weber, Gospodarka i społeczeństwo. Zarys socjologii rozumiejącej, tłum. D. Lachowska.

Warszawa: PWN.

Lévinas E. (1998), Catość i nieskończoność, tłum. M. Kowalska. Warszawa: PWN.

Limanowski B. (1906) Naród i państwo. Studium socjologiczne. Kraków.

Limanowski B. (1911), Odrodzenie i rozwój narodowości polskiej na Śląsku. Kraków.

Limanowski B. (1918), Państwo unarodowione i unarodowienie ziemi, Warszawa.

Limanowski B. (1921), Socjologia, część I. Kraków-Warszawa: Gebethner i Wolf.

Limanowski B. (1921), Socjologia, część II. Kraków-Warszawa: Gebethner i Wolf.

Limanowski B. (1946), Historia demokracji polskiej, część I i II. Warszawa: Spółdzielnia Wydawnicza „Wiedza”.

Łepkowski T. (1967), Polska - narodziny nowoczesnego narodu 1764-1870. Warszawa: PWN.

Mencwel A. (1990), Etos lewicy. Esej o narodzinach kulturalizmu polskiego. Warszawa: PIW.

Miłosz C. (2000), Cztowiek wśród skorpionów. Studium o Stanistawie Brzozowskim. Kraków: Wydawnictwo ZNAK.

Newman J.H. (1915), Przyświadczenie wiary, przekład z przedmową S. Brzozowskiego. Lwów: Biblioteka Sympozjonu. Platon (1960), Prawa, tłum. M. Maykowska, Warszawa: PWN.

Plotyn (1959), Enneady, tłum. i wstęp A. Krokiewicz. Warszawa: PWN.

Popper R.K. (1993), Spoteczeństwo otwarte i jego wrogowie, t. 1, Urok Platona, tłum. H. Krahelska, oprac. A. Chmielewski. Warszawa: PWN.

Reed I. (2008), Justifying Sociological Knowledge: From Realism to Interpretation, „Sociological Theory”, vol. 28(2).

Sewell H.W. Jr (1980), Work and Revolution in France: The Language of Labor from the Old Regime to 1848. New York: Cambridge University Press.

Sewell H.W. Jr (1992), A Theory of Structure: Duality, Agency and Transformation, „American Journal of Sociology”, vol. 98, s. 1-29.

Sharpe E. (1986), Comparative Religion: A History, 2nd edn. La Salle, III, Open Court.

Smith Z.J. (1979), Map is not Territory: Studies in the History of Religions. Chicago: University of Chicago Press.

Smith Z.J. (1987), To take Place. Toward Theory in Ritual. Chicago: University of Chicago Press.

Smith Z.J. (2005), Relating Religion: Essays in the Study of Religion. Chicago: University of Chicago Press.

Snyder T. (2010), Nacjonalizm, marksizm i nowoczesna Europa Środkowa. Biografia Kazimierza Kelles-Krauza (1872-1905).

Warszawa: Wydawnictwo Krytyki Politycznej.

Steinmetz G. (1998), Critical Realism and Historical Sociology, „Comparative Studies in Society and History”, vol. 40(1). Stein E. - Święta Teresa Benedykta od Krzyża (2002), Autoportret z listów (1916-1933), tłum. I. Adamska OCD,

A. Talarek. Kraków: Wydawnictwo Karmelitów Bosych.

Szacki J. (1991), Dylematy historiografii idei. Warszawa: PWN.

Tarkowska E. (1990), Wstęp [w:] E. Durkheim, Elementarne formy życia religijnego. Warszawa: PWN.

The New Institutionalism in Organizational Analysis (1991), edited by W.W. Powell, P.J. Di Maggio. London: The University of Chicago Press, Chicago.

Walicki A. (1990), Filozofia dojrzatości dziejowej [w:] S. Brzozowski (1990), Idee, Kraków: Wydawnictwo Literackie. Weber M. (1976), The Agrarian Sociology of Ancient Civilizations. London: New Left Book. 
Weber M. (2000), Etyka gospodarcza religii światowych, t. 1-3. Kraków: NOMOS.

Weber M. (2002), Gospodarka i spoteczeństwo. Zarys socjologii rozumiejącej, tłum. i wstęp D. Lachowska. Warszawa: PWN.

Wereszycki H. (1975), Pod bertem Habsburgów. Zagadnienia narodowościowe. Kraków: Wydawnictwo Literackie. Żeromski S. (1957), Uroda życia. Warszawa: Czytelnik. 